\title{
Serotonin and the 5- $\mathrm{HT}_{2 \mathrm{~B}}$ Receptor in the Development of Enteric Neurons
}

\author{
Elena Fiorica-Howells, ${ }^{1}$ Luc Maroteaux, ${ }^{2}$ and Michael D. Gershon ${ }^{1}$ \\ Department of Anatomy and Cell Biology, Columbia University, College of Physicians and Surgeons, New York, New York \\ 10032, and 2Institut de Génétique et de Biologie Moléculaire et Cellulaire, Université Louis Pasteur de Strasbourg, Centre \\ National de la Recherche Scientifique, Institut National de la Santé et de la Recherche Médicale, BP 163-67404, Illkirch \\ Cedex-France
}

\begin{abstract}
We tested the hypothesis that 5-HT promotes the differentiation of enteric neurons by stimulating a developmentally regulated receptor expressed by crest-derived neuronal progenitors. 5-HT and the 5- $\mathrm{HT}_{2}$ agonist ( \pm )-2,5-dimethoxy-4iodoamphetamine $\mathrm{HCl}(\mathrm{DOI})$ enhanced in vitro differentiation of enteric neurons, both in dissociated cultures of mixed cells and in cultures of crest-derived cells isolated from the gut by immunoselection with antibodies to $\mathrm{p} 75^{\mathrm{NTR}}$. The promotion of in vitro neuronal differentiation by $5-\mathrm{HT}$ and $\mathrm{DOI}$ was blocked by the $5-\mathrm{HT}_{1 / 2}$ antagonist methysergide, the pan-5- $\mathrm{HT}_{2}$ antagonist ritanserin, and the $5-\mathrm{HT}_{2 \mathrm{~B} / 2 \mathrm{C}}$-selective antagonist SB206553. The 5- $\mathrm{HT}_{2 \mathrm{~A}}$-selective antagonist ketanserin did not completely block the developmental effects of 5-HT. 5-HT induced the nuclear translocation of mitogen-activated protein kinase. This effect was blocked by ritanserin. mRNA encoding $5-\mathrm{HT}_{2 \mathrm{~A}}$ and
\end{abstract}

The gut is the only organ that is able to display reflex activity when isolated from the CNS (Furness and Costa, 1987; Gershon et al., 1994). This activity is mediated by the intrinsic innervation of the bowel, the enteric nervous system (ENS), which structurally and chemically has more in common with the CNS than with the extraenteric peripheral nerve. Despite its unique properties, the ENS shares the neural crest origin of most of the PNS (Yntema and Hammond, 1954, 1955; Le Douarin and Teillet, 1973, 1974). At least some migrating crest-derived cells are pluripotent (Fraser and Bronner-Fraser, 1991; Ito and Sieber-Blum, 1993; Ito et al., 1993; Sieber-Blum et al., 1993) and remain so at the time they colonize the gut (Rothman et al., 1990, 1993; Sextier-SainteClaire Deville et al., 1994; Lo and Anderson, 1995). The enteric microenvironment, therefore, plays a role in determining the ENS-specific outcome of the differentiation of crest-derived cells within the bowel (Gershon, 1997, 1998).

Signals that influence the fate of crest-derived neural and glial precursors in the enteric microenvironment are known to include glial cell line-derived neurotrophic factor (Moore et al., 1996; Pichel et al., 1996; Sánchez et al., 1996; Chalazonitis et al., 1998b;

\footnotetext{
Received June 11, 1999; revised Sept. 20, 1999; accepted Oct. 12, 1999.

This work was supported by National Institutes of Health Grants NS12969 and NS15547 to M.D.G. and HD35632 to E.F.-H. Confocal microscopy was supported by National Institutes of Health Grants RR10506 and CA13696. We thank Valerie Boone and Kenneth Chen for their expert technical assistance.

Correspondence should be addressed to Dr. Elena Fiorica-Howells, Department of Anatomy and Cell Biology, Columbia University, College of Physicians and Surgeons, 630 West 168th Street, New York, NY 10032. E-mail address: ef7@columbia.edu.

Copyright (C) 1999 Society for Neuroscience $0270-6474 / 99 / 200294-12 \$ 15.00 / 0$
}

$5-\mathrm{HT}_{2 \mathrm{~B}}$ receptors was detected in the fetal bowel (stomach and small and large intestine), but that encoding the $5-\mathrm{HT}_{2 \mathrm{C}}$ receptor was not. mRNA encoding the $5-\mathrm{HT}_{2 \mathrm{~B}}$ receptor and $5-\mathrm{HT}_{2 \mathrm{~B}}$ immunoreactivity were found to be abundant in primordial [embryonic day 15 (E15)-E16] but not in mature myenteric ganglia. $5-\mathrm{HT}_{2 \mathrm{~B}}$-immunoreactive cells were found to be a subset of cells that expressed the neuronal marker PGP9.5. These data demonstrate for the first time that the $5-\mathrm{HT}_{2 \mathrm{~B}}$ receptor is expressed in the small intestine as well as the stomach and that it is expressed by enteric neurons as well as by muscle. It is possible that by stimulating $5-\mathrm{HT}_{2 \mathrm{~B}}$ receptors, $5-\mathrm{HT}$ affects the fate of the large subset of enteric neurons that arises after the development of endogenous sources of 5-HT.

Key words: enteric nervous system; bowel; gut; neuronal development; serotonin receptors; 5-HT
Hearn et al., 1998), neurotrophin-3 (Chalazonitis et al., 1994), neuropoietic cytokines (Gershon, 1997; Chalazonitis et al., 1998a), endothelin-3 (Baynash et al., 1994), and laminin-1 (Rothman et al., 1996; Chalazonitis et al., 1997). It has been suggested that early-developing enteric neurons, or their transmitters, might also influence the fate of later-developing cells because different types of enteric neurons arise in a reproducible sequential order (Pham et al., 1991). In fact, differential dependence on the expression of the mash-1 gene has enabled early- and latedeveloping enteric neuronal precursor lineages to be clearly distinguished (Blaugrund et al., 1996). The mash-1-dependent cells are transiently catecholaminergic before they acquire their terminally differentiated phenotype. These cells leave the cell cycle and give rise to neurons at a time when the mash-1-independent progenitors are still proliferating (Blaugrund et al., 1996). Early neurons even form synapses on dividing neuroblasts (Gershon et al., 1981). All enteric serotonergic neurons are mash-1 dependent and develop early (Pham et al., 1991; Blaugrund et al., 1996). 5-HT could thus influence the fate of late-developing neurons. Enterochromaffin cells (EC), which are by far the largest enteric source of 5-HT, also develop before the mash-1-independent lineage of enteric neurons (Branchek and Gershon, 1989). 5-HT may thus be a growth and/or survival factor, as well as a neurotransmitter or paracrine hormone (Cooke et al., 1997; Chen et al., 1998; Gershon, 1999).

Although 5-HT's ability to act as a growth factor has not yet been directly demonstrated, indirect evidence suggests that 5-HT does play a role in the development of neurons (Lauder and Krebs, 1978; Lauder, 1988, 1993; Azmitia et al., 1990; Whitaker- 
Azmitia et al., 1990; Nishi et al., 1996), glia (Liu and Lauder, 1992), and mesenchymal cells (Shuey et al., 1992, 1993; Choi et al., 1994, 1997). 5-HT may also affect phenotypic choice, for example, by increasing the proportion of CNS neuroblasts that develop as glutaminergic neurons (Lavdas et al., 1997). The current study was performed to test the hypothesis that 5-HT promotes enteric neuronal differentiation by stimulating a developmentally regulated subtype of the 5-HT receptor. The data show that the $5-\mathrm{HT}_{2 \mathrm{~B}}$ receptor is both highly expressed and developmentally regulated in primordial enteric ganglia. 5-HT promotes the in vitro development of enteric neurons by an action that can be blocked by antagonizing $5-\mathrm{HT}_{2 \mathrm{~B}}$ receptors. $5-\mathrm{HT}_{2 \mathrm{~B}}$ expression temporally follows that of sources of 5-HT and coincides with the period of terminal differentiation of mash-1independent enteric neurons; therefore, these observations are consistent with the possibility that stimulation of $5-\mathrm{HT}_{2 \mathrm{~B}}$ receptors by 5-HT influences the fates of late-developing enteric neurons.

\section{MATERIALS AND METHODS}

Animals and tissue collection. Adult Sprague Dawley rats (Charles River Laboratories, Wilmington, MA) were anesthetized with methoxyflurane (Pitman Moore) and decapitated. Guinea pigs (Kingstar Laboratories) were stunned and exsanguinated. Mice (CD-1 strain; Charles River Laboratories) were killed by asphyxiation, followed by cervical dislocation. Fetuses, obtained from timed pregnant mice, were anesthetized by cooling and exsanguinated before dissection. All procedures were approved by the Animal Care and Use Committee of Columbia University.

Cell culture. Experiments were performed with dissociated cells obtained from the intestines of $10-15$ fetuses (removed from one or two dams) at embryonic day 13 (E13)-E15. The entire bowel was dissected, minced, and digested with collagenase A $(5 \mathrm{mg} / \mathrm{ml})$ in saline- $\mathrm{G}$ (in $\mathrm{mM}$, $\mathrm{NaCl} 137, \mathrm{KCl} 5.4, \mathrm{Na}_{2} \mathrm{HPO}_{4} 1.1, \mathrm{KH}_{2} \mathrm{PO}_{4} 1.1$, and glucose $0.11 \%, \mathrm{pH}$ 7.2-7.4) for $30 \mathrm{~min}$ at $37^{\circ} \mathrm{C}$. After digestion, cells were dissociated by trituration in defined media (Stemple and Anderson, 1992). The dissociated cells $\left(6.0 \times 10^{4} / 0.5 \mathrm{ml}\right.$ sample $)$ were plated on laminin-coated glass coverslips, held in four-well tissue culture plates, and grown in serumfree defined media (Stemple and Anderson, 1992). Experimental compounds or vehicle (controls) was added after $24 \mathrm{hr}$ in vitro. Cultured cells were fixed after 3 or $7 \mathrm{~d}$ of incubation. When cells were cultured for $7 \mathrm{~d}$, the medium was changed at day 3. Cultures were maintained in triplicate. Cultured cells were fixed for $1 \mathrm{hr}$ with $4 \%$ formaldehyde (freshly prepared from paraformaldehyde) in PBS (130 $\mathrm{mm} \mathrm{NaCl}, 7 \mathrm{~mm}$ $\mathrm{Na}_{2} \mathrm{HPO}_{4}$, and $3 \mathrm{~mm} \mathrm{NaH}_{2} \mathrm{PO}_{4}$ ). Compounds tested were the following: 5-HT, ( \pm )-2,5-dimethoxy-4-iodoamphetamine $\mathrm{HCl}$ (DOI), ritanserin, SB206553 (Research Biochemicals, Natick, MA), methysergide (Sandoz, Basel, Switzerland), and ketanserin (Janssen Biochimica, Berse, Belgium).

Immunoselection. Crest-derived cells of the E14 gut were separated from noncrest-derived cells by positive and negative immunoselection as described previously (Pomeranz et al., 1993; Chalazonitis et al., 1994, 1997, 1998a). Antibodies to the common neurotrophin receptor p $75^{\text {NTR }}$ (\#9651; generously supplied by Dr. Moses Chao, Cornell University Medical College, New York, NY) (Huber and Chao, 1995) were used to immunoselect the crest-derived population.

Reverse transcription and the PCR. RNA was extracted from segments of mature or fetal bowel using the guanidinium thiocyanate method (Chomczynski and Sacchi, 1987). Reverse transcription (RT)-PCR was used to detect expression of mRNA-encoding members of the 5- $\mathrm{HT}_{2}$ receptor family in sampled regions of the gut. The set of PCR primers used for the analysis of the 5- $\mathrm{HT}_{2 \mathrm{~A}}$ receptor, 5'-ATGGAAATTCTCTGTGAAGACAATATCTCC $-3^{\prime}$ and 5' -TCACACACAGCTAACCTTTTCATTCACGGT-3', corresponded to nucleotides (nt) 1-30 and 1387-1416, respectively, of the murine receptor (Yang et al., 1992). The set of PCR primers used for the analysis of the $5-\mathrm{HT}_{2 \mathrm{~B}}$ receptor, 5'-ATGGCTTCATCTTATAAAATGTCTGAAA-3' and 5'-ATCGAGGAGGATGATTGATGAGGACTGAATGGTTGA-3', corresponded to nt 19-45 and 1366-1401, respectively, of the murine receptor (Loric et al., 1992). The set of PCR primers used for the analysis of the 5-HT ${ }_{2 \mathrm{C}}$ receptor, 5'-TAATTGGCCTATTGGTTT-3' and 5'-ACACTACTAATCCTCT-3', corresponded to nt 44-61 and 1361-1376, respec- tively, of the murine receptor (Yu et al., 1991). For first-strand cDNA synthesis, $2.5 \mu \mathrm{g}$ of RNA was incubated for $1 \mathrm{hr}$ at $42^{\circ} \mathrm{C}$ with $200 \mathrm{U}$ of Moloney murine leukemia virus reverse transcriptase, using random primers at a concentration of $2.5 \mu \mathrm{M}$. This reaction and subsequent amplification with Taq polymerase was performed with a commercial kit (GeneAmp; Perkin-Elmer, Emeryville, CA) according to the manufacturer's instructions. The PCR profile of $93^{\circ} \mathrm{C}$ for $2 \mathrm{~min}, 55^{\circ} \mathrm{C}$ for $2 \mathrm{~min}$, and $72^{\circ} \mathrm{C}$ for $4 \mathrm{~min}$ for 30 cycles was programmed into a model PTC-150 programmable thermal cycler (MJ Research, Watertown, MS). PCR reaction products were resolved on $1.2 \%$ agarose, $40 \mathrm{~mm}$ Tris-acetate, and $1 \mathrm{~mm}$ EDTA gels, and their size was determined using a $123 \mathrm{bp}$ standard ladder.

Riboprobe biosynthesis. PCR products, amplified with primers designed on the basis of sequences found between the third and sixth transmembrane domains of the rat 5- $\mathrm{HT}_{2 \mathrm{~B}}$ receptor, were obtained from mouse, rat, and guinea pig tissues. These fragments were $620 \mathrm{bp}$ (mouse), $606 \mathrm{bp}$ (rat), and $611 \mathrm{bp}$ (guinea pig). For subcloning, the PCR fragments were extracted from agarose gels (Gene-Clean; BIO 101, La Jolla, CA) and ligated into the cloning vector pCRII using the T/A cloning kit (Invitrogen, San Diego, CA). PCR fragments were sequenced using the Sanger dideoxynucleotide chain termination method (Sanger et al., 1977). cDNA fragments encoding the partial sequence of the $5-\mathrm{HT}_{2 \mathrm{~B}}$ receptor for each species were used as templates for the synthesis of sense and antisense $\left[{ }^{35} \mathrm{~S}\right]$-labeled riboprobes using a commercial kit according to the manufacturer's directions (Promega, Madison, WI).

In situ hybridization. mRNA encoding the $5-\mathrm{HT}_{2 \mathrm{~B}}$ receptor was located by in situ hybridization in mouse, rat, and guinea pig tissues. Dissected preparations were cleaned and fixed for $4 \mathrm{hr}$ (fetal) or $3 \mathrm{hr}$ (adult) in 4\% formaldehyde (freshly prepared from paraformaldehyde) in PBS. The fixed tissues were then cryoprotected by overnight incubation in $30 \%$ sucrose at $4^{\circ} \mathrm{C}$, embedded in ornithine carbamyl transferase (OCT) compound (Tissue-Tek), frozen in liquid $\mathrm{N}_{2}$, and sectioned at $-20^{\circ} \mathrm{C}$ with a cryostat microtome. Cross sections were cut through dissected segments of bowel or the abdominal cavities of fetal mice. The sections were thaw-mounted onto Tespa (Sigma, St. Louis, MO)-coated slides and stored at $-80^{\circ} \mathrm{C}$ until used.

Tissue sections were post-fixed on slides with formaldehyde (4\%, freshly prepared from paraformaldehyde) in PBS, containing $50 \mathrm{~mm}$ EDTA, for $3 \mathrm{~min}$ at room temperature. The sections were rinsed twice in PBS and once in water, dehydrated by passage through a graded series of ethanols, air dried for $5 \mathrm{~min}$, rehydrated ( $2 \mathrm{~min}$ ), and transferred to 50 $\mathrm{mm}$ triethanolamine. Acetic anhydride was added to yield a final concentration of $0.25 \%$, and the sections were left for $10 \mathrm{~min}$. After a $10 \mathrm{~min}$ rinse in $0.2 \times \mathrm{SSC}(1 \times \mathrm{SSC}, 150 \mathrm{~mm} \mathrm{NaCl}$ and $15 \mathrm{~mm} \mathrm{Na}$ citrate, $\mathrm{pH} 7)$, the sections were again dehydrated in a series of increasing concentrations of ethanol and air dried. Sections were prehybridized for $2 \mathrm{hr}$ at $50^{\circ} \mathrm{C}$ in $250 \mu \mathrm{l}$ of a solution containing $50 \%$ formamide, $600 \mathrm{~mm} \mathrm{NaCl}, 10$ mM Tris-HCl, pH 7.5, 1 mM EDTA, $1 \times$ Denhardt's solution, $0.05 \%$ boiled salmon sperm DNA, and $0.0125 \%$ yeast tRNA in a chamber humidified by a solution of $4 \times$ SSC containing $50 \%$ formamide. The sections were then hybridized overnight at $50^{\circ} \mathrm{C}$ with ${ }^{35} \mathrm{~S}$-antisense or ${ }^{35} \mathrm{~S}$-sense $5-\mathrm{HT}_{2 \mathrm{~B}}$ riboprobes. The probes were diluted $(50,000 \mathrm{cpm} / \mu \mathrm{l})$ in a hybridization buffer containing $50 \%$ formamide, $600 \mathrm{~mm} \mathrm{NaCl}, 10$ mm Tris-HCl, $\mathrm{pH} 7.5,1 \mathrm{~mm}$ EDTA, $1 \times$ Denhardt's solution, $10 \%$ dextran sulfate, $0.01 \%$ boiled salmon sperm DNA, $0.0125 \%$ yeast tRNA, $10 \mathrm{~mm}$ DTT, and $0.1 \%$ SDS. The slides were washed for $30 \mathrm{~min}$ at $50^{\circ} \mathrm{C}$ in a solution containing $50 \%$ formamide, $1 \times$ SSC, and $10 \mathrm{~mm}$ DTT. Formamide was removed by washing slides at room temperature in $0.5 \times$ SSC for $30 \mathrm{~min}$. Sections were treated with RNase A $(100 \mu \mathrm{g} / \mathrm{ml})$ in buffer (10 mm Tris-HCl, pH 7.5, $1 \mathrm{~mm}$ EDTA, and $500 \mathrm{~mm} \mathrm{NaCl})$ for 30 $\mathrm{min}$ at room temperature and rinsed in the same buffer (twice for $10 \mathrm{~min}$ each; room temperature) and then in $0.5 \times$ SSC (twice for $60 \mathrm{~min}$ each; $50^{\circ} \mathrm{C}$ ). Finally, the sections were dehydrated in ethanol containing 300 $\mathrm{mm}$ ammonium acetate and air dried. Slides were dipped in liquified Ilford L4 emulsion (diluted 1:1), dried, and exposed for 16-20 weeks (adult tissue) or 4-8 weeks (fetal tissue) at room temperature before development with Kodak Microdol X (Eastman Kodak, Rochester, NY). Developed slides either were viewed unstained or were counterstained with Geimsa, dehydrated, and mounted with Permount. Sections were examined with a Leica DMRB microscope (Nussloch, Germany) using bright-field and/or vertical dark-field illumination.

Immunocytochemistry. Both fresh-frozen and fixed preparations were examined. Freshly dissected and fixed tissues were infiltrated with OCTembedding medium, frozen in liquid $\mathrm{N}_{2}$, sectioned $(10 \mu \mathrm{m})$ with a cryostat microtome, and collected on gelatin-coated glass slides. Sections 
of fresh-frozen tissue were fixed on slides (1\% formaldehyde; $10 \mathrm{~min}$; $4^{\circ} \mathrm{C}$ ) and washed (twice for $10 \mathrm{~min}$ each) with PBS containing $0.1 \%$ Triton X-100 (PBS-T). All preparations were treated for $30 \mathrm{~min}$ with $\mathrm{H}_{2} \mathrm{O}_{2}(0.3 \%)$ in PBS-T, washed again with PBS-T, and blocked for $30 \mathrm{~min}$ with $4 \%$ goat serum (GS) in PBS containing $0.3 \%$ Triton X-100. Polyclonal (Choi and Maroteaux, 1996) or monoclonal (PharMingen, San Diego, CA) antibodies to the 5- $\mathrm{HT}_{2 \mathrm{~B}}$ receptor were then applied (diluted 1:100 in blocking solution) to the sections for $72 \mathrm{hr}$ at $4^{\circ} \mathrm{C}$. Cells in culture were fixed and treated as described above. Sites of antibody binding were detected with biotinylated species-specific secondary antibodies and avidin coupled to horseradish peroxidase (ABC method; Elite Kit; Vector Laboratories, Burlingame, CA). Peroxidase activity was visualized with $\mathrm{H}_{2} \mathrm{O}_{2}$ and 3,3'-diaminobenzidene and nickel intensification. Alternatively, double-label fluorescence immunocytochemistry was used to identify the neuronal marker ubiquitin hydrolase (PGP9.5; diluted 1:500) (Wilkinson et al., 1989) together with 5- $\mathrm{HT}_{2 \mathrm{~B}}$ receptors. 5- $\mathrm{HT}_{2 \mathrm{~B}}$ immunoreactivity was detected with indocarbocyanine (Cy3)-labeled goat anti-mouse antibodies (diluted 1:2000) or biotinylated goat $\mathrm{F}\left(\mathrm{ab}^{\prime}\right)_{2}$ anti-mouse $\operatorname{IgG1}\left(\gamma_{1}\right.$ chain specific; diluted 1:100; Southern Biotechnology, Birmingham, AL) and steptavidin coupled to Cy3 (diluted 1:1000; Jackson ImmunoResearch, West Grove, PA). PGP9.5 immunoreactivity was visualized with fluorescein isothiocyanate (FITC)-labeled secondary antibodies (diluted 1:1000; Jackson ImmunoResearch).

For studies of the development of neurons in vitro, the PGP9.5 immunoreactivity was again used as a neural marker. For these experiments, fixed cultures were permeabilized with $4 \%$ GS in PBS containing $0.1 \%$ Triton X-100. PGP9.5 immunoreactivity was visualized with biotinylated goat anti-rabbit IgG (diluted 1:400; Kirkegaard \& Perry, Gaithersburg, MD) and streptavidin coupled to FITC (diluted 1:200; Vector Laboratories). The PGP9.5-immunoreactive cells were counted at a magnification of $100 \times$, using a rectangle projected into the viewing oculars. Sampling errors were avoided by counting every PGP9.5-immunoreactive cell on each coverslip. To estimate the total numbers of cells in each culture, we stained the same cultures used for demonstrating PGP9.5 immunoreactivity with bisbenzamide $(1.0 \mu \mathrm{g} / \mathrm{ml}$ for $5 \mathrm{~min}$ followed by two washes). Because bisbenzamide inserts into DNA, nuclei could be accurately counted, and cell numbers were determined from the nuclear counts. All conditions were analyzed in triplicate in each experiment; means were compared by ANOVA, using the STATVIEW 4.0 program for the Macintosh computer. In all instances, $p<0.05$ was considered significant. No significant differences were found between conditions in total cell numbers within each experiment.

\section{RESULTS}

\section{5-HT promotes the development of enteric neurons in vitro by stimulating a $5-\mathrm{HT}_{2}$ receptor}

Fetal mouse gut was dissociated at E13-E16. This period precedes the differentiation of mash-1-independent neurons (Blaugrund et al., 1996) yet still encompasses both the birth of enteric serotonergic neurons (Pham et al., 1991) and the acquisition of their neurotransmitter (Rothman and Gershon, 1982). Cells were cultured in serum-free defined media. Neurons (identified as PGP9.5-immunoreactive cells) developed well under these conditions. In initial studies, cultured cells were exposed to 5-HT (1 or $10 \mu \mathrm{M}$ ) for $48 \mathrm{hr}$. 5-HT increased both the number of neurons (PGP9.5-immunoreactive cells) developing in vitro $(p<0.01$ vs control, for 1 and $10 \mu \mathrm{M})$ and the extent of branching of their neurites (Figs. $1,2 A, B$ ). The $5-\mathrm{HT}_{1 / 2}$ antagonist methysergide (10 $\mu \mathrm{M}$ ), by itself, exerted no effect on neuronal development (Figs. 1, $2 C$ ); however, methysergide blocked both the 5-HT-associated promotion of neuronal development ( $p<0.001$ vs $1.0 \mu \mathrm{M} 5-\mathrm{HT}$ ) and the enhancement of neuritic branching (Figs. 1, compare $2 D$ with $B$ ).

In subsequent experiments, dissociated enteric cells were exposed to 5-HT for $144 \mathrm{hr}$ to provide additional time for its actions to become manifest. 5-HT (1 $\mu \mathrm{M})$ again increased the number of neurons developing in vitro (Fig. 3). The average number of neurons found in cultures of mixed cells dissociated from the fetal

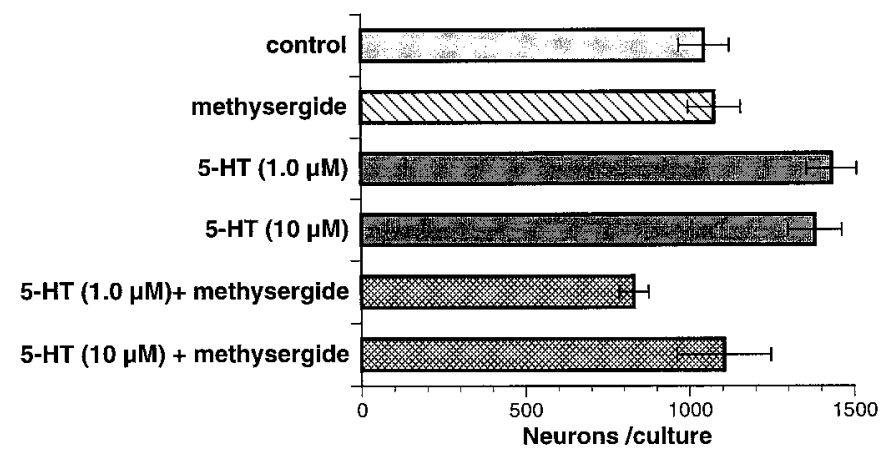

Figure 1. 5-HT promotes the development of neurons in vitro, and this effect is blocked by methysergide. Intestinal cells (E16) were dissociated and cultured in the presence of vehicle (control) or the indicated experimental compounds for $48 \mathrm{hr}$. The concentration of methysergide was 10 $\mu \mathrm{M}$. All of the neurons (PGP9.5-immunoreactive cells) on each cultured dish were counted. Data are presented as the actual number of neurons found in each dish. The total number of cells per culture does not differ significantly between conditions.

bowel was $1415 \pm 120$ neurons $(n=28)$, which represents $\sim 10 \%$ of the total number of cells per culture $(14,727 \pm 630)$. Although there were now many more neurons, the magnitude of the increase evoked by the addition of 5-HT (approximately twofold) was approximately the same as that seen in cultures exposed to 5-HT for only $48 \mathrm{hr}$. The 5-HT 2 agonist DOI (1 $\mu \mathrm{M})$ mimicked the effects of 5-HT and increased both the number of neurons developing in vitro ( $p<0.001$ vs control for both 5-HT and DOI) and the complexity of neuritic branching. The response to DOI was greater than that to the same concentration of 5-HT $(p<$ 0.001 vs $5-\mathrm{HT})$. The selective $5-\mathrm{HT}_{2}$ antagonist ritanserin $(0.1$ $\mu \mathrm{M})$ abolished the effects, both of 5-HT ( $p<0.001$ vs 5-HT) and DOI ( $p<0.001$ vs DOI) (Fig. 3).

In contrast to ritanserin, the $5-\mathrm{HT}_{2 \mathrm{~A}}$ selective antagonist ketanserin $(0.1 \mu \mathrm{M})$ did not completely prevent the stimulation of neuronal development by 5-HT or DOI (Fig. 3). Both 5-HT (1.0 $\mu \mathrm{M} ; p<0.001$ vs control) and DOI $(1.0 \mu \mathrm{M} ; p<0.03$ vs control $)$ continued to promote neuronal development, despite the presence of ketanserin. Ketanserin moderately reduced the number of neurons developing in the presence of DOI $(p<0.001$ vs DOI). The observation that ritanserin completely antagonizes the promotion of the in vitro development of enteric neurons by 5-HT and DOI suggests that stimulation of a $5-\mathrm{HT}_{2}$ receptor is sufficient to account for the response. Because ketanserin $(0.1 \mu \mathrm{M}) \mathrm{did}$ not completely block the response to 5-HT and DOI but ritanserin $(0.1 \mu \mathrm{M})$ did, the pharmacology of the receptors that mediate the 5-HT- and DOI-induced enhancement of neuronal development seems to be more like that of a $5-\mathrm{HT}_{2 \mathrm{~B}}$ and/or $5-\mathrm{HT}_{2 \mathrm{C}}$ than a $5-\mathrm{HT}_{2 \mathrm{~A}}$ receptor.

\section{Enteric crest-derived cells respond directly to 5-HT}

To determine whether 5-HT and/or DOI promoted the development of neurons by acting directly on their crest-derived progenitors, we cultured isolated populations (E14) of crest- and noncrest-derived cells for $3 \mathrm{~d}$ in the presence or absence of 5-HT or DOI. The isolated cells were obtained by a process of positive and negative immunoselection with antibodies to $\mathrm{p} 75^{\mathrm{NTR}}$. 5-HT $(p<0.001)$ and DOI $(p<0.001)$ were each found to promote the development of neurons at least as well in cultures of isolated crest-derived cells as in mixed cultures of crest- and noncrestderived cells (Fig. 4; compare with Figs. 1, 3). The antagonist SB206553, which has an $\sim 500$-fold greater affinity for $5-\mathrm{HT}_{2 \mathrm{~B}}$ and 

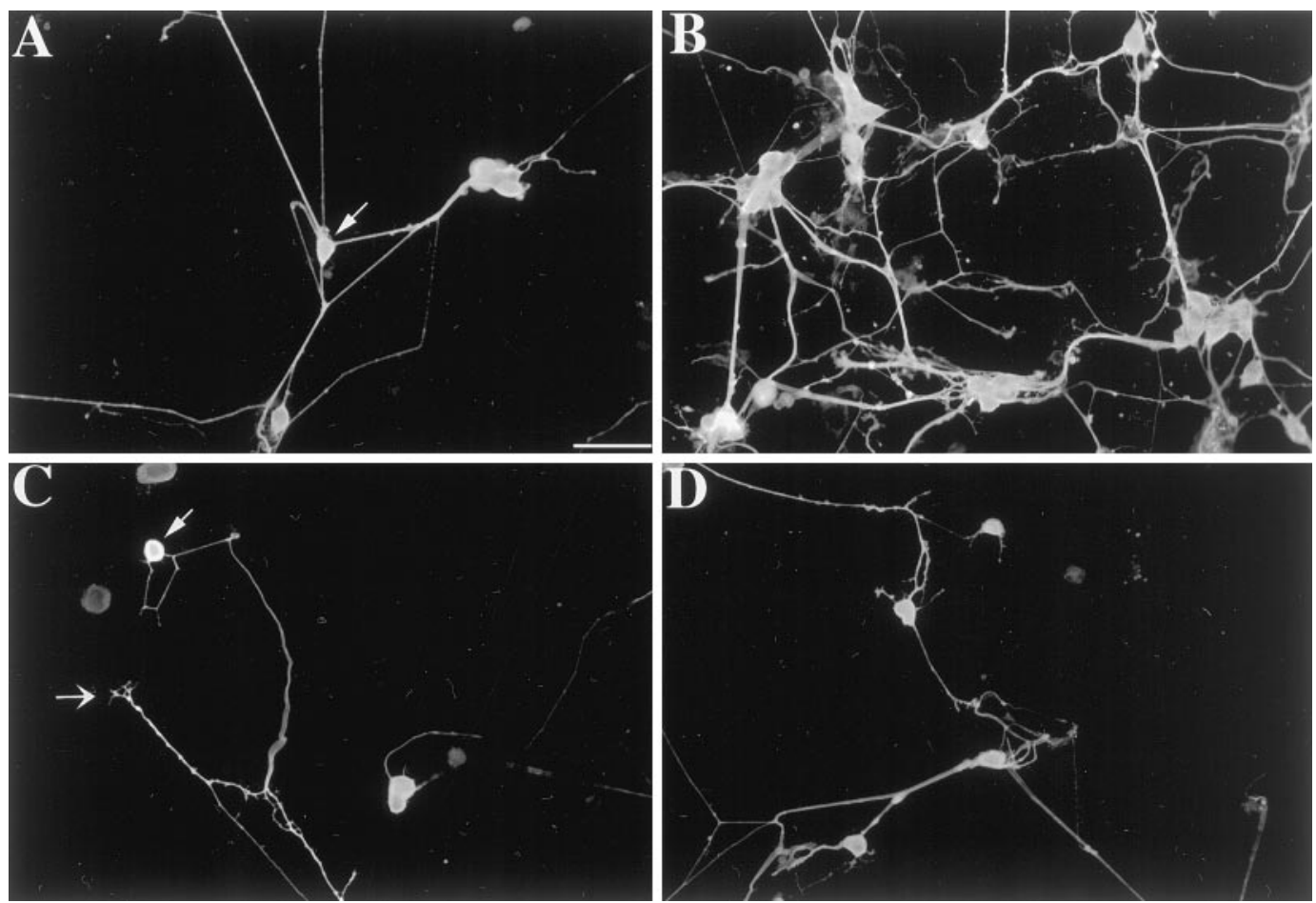

Figure 2. The effects of 5-HT on neuronal development were visualized by demonstrating the immunoreactivity of the neuronal marker PGP9.5. Cultures were prepared and treated as described in Figure 1. Nerve cell bodies $(\rightarrow)$ and a growth cone $(\rightarrow)$ are indicated. $A$, Control. $B, 5$-HT $(1.0 \mu \mathrm{M})$. $C$, Methysergide $(10.0 \mu \mathrm{M})$. D, 5-HT $(1.0 \mu \mathrm{M})+$ methysergide $(10.0 \mu \mathrm{M})$. 5-HT increases both the number of neurons and the complexity of the branching of their neurites. Methysergide does not itself affect the number or appearance of cultured neurons but blocks the effects of 5-HT. Scale bar, $50 \mu \mathrm{m}$.

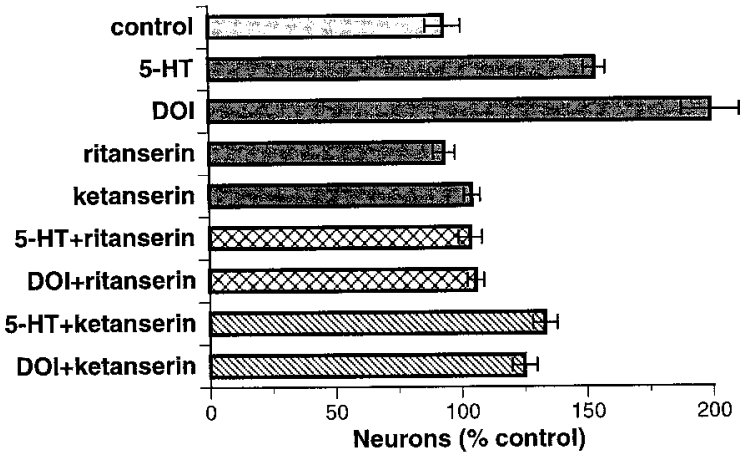

Figure 3. The effects of 5-HT on in vitro neuronal development are mimicked by DOI and antagonized by ritanserin more than ketanserin. Intestinal cells (E14) were dissociated and cultured in the presence of vehicle (control) or the indicated experimental compounds for $144 \mathrm{hr}$. All of the neurons (PGP9.5-immunoreactive cells) on each cultured dish were counted. Concentrations were as follows: 5-HT, $1.0 \mu \mathrm{M}$; DOI, $1.0 \mu \mathrm{M}$; ritanserin, $0.1 \mu \mathrm{M}$; and ketanserin, $0.1 \mu \mathrm{M}$.

5- $\mathrm{HT}_{2 \mathrm{C}}$ than for 5- $\mathrm{HT}_{2 \mathrm{~A}}$ receptors (Audia et al., 1996; Kennett et al., 1996), was used to test the premise that the growth factor-like actions of 5 -HT are mediated by a $5-\mathrm{HT}_{2 \mathrm{~B} / 2 \mathrm{C}}$ receptor. $\mathrm{SB} 206553$ $(1.0 \mu \mathrm{M})$ antagonized both the increase in development of enteric neurons induced by 5 -HT $(1.0 \mu \mathrm{M} ; p<0.01)$ and that induced by DOI $(1.0 \mu \mathrm{M} ; p<0.001)$. Virtually no neurons could be detected in the cultures of noncrest-derived cells, whether or not these cells were exposed to 5-HT or DOI (data not shown).

\section{5-HT activates mitogen-activated protein kinase in developing enteric neurons in vitro}

When transfected cells expressing $5-\mathrm{HT}_{2 \mathrm{~B}}$ receptors are exposed to 5-HT, mitogen-activated protein kinases (MAPKs) are stim-

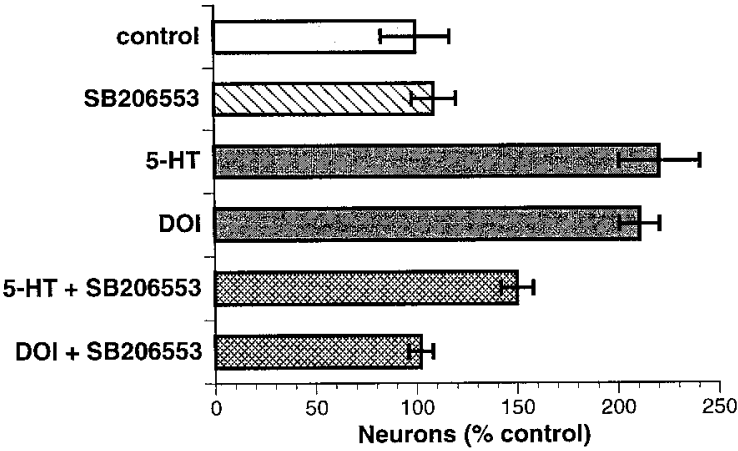

Figure 4. 5-HT and DOI promote the development of neurons in cultures of isolated enteric crest-derived cells. The effects of both compounds are blocked by a selective $5-\mathrm{HT}_{2 \mathrm{~B} / 2 \mathrm{C}}$ antagonist, SB206553. Concentrations were as follows: SB206553, $1.0 \mu \mathrm{M}$; 5-HT, $1.0 \mu \mathrm{M}$; and DOI, $1.0 \mu \mathrm{M}$.

ulated (Launay et al., 1996). The activation of MAPKs in enteric neuronal precursors by 5-HT might, if it occurred, foster the proliferation of cycling precursors and/or the differentiation and survival of postmitotic neurons (Marshall, 1995). We therefore tested the hypothesis that stimulation of $5-\mathrm{HT}_{2}$ receptors activates MAPKs in enteric crest-derived cells. These studies were performed by immunocytochemistry, using antibodies that specifically detect the Y204-phosphorylated forms of both p42 (Erk1) and p44 (Erk2) MAPKs (Yan and Zahradka, 1997). Because phosphorylation causes the p42 and p44 MAPKs to become catalytically active and translocated to the nucleus in stimulated cells, the detection of intranuclear immunoreactivity was taken as indicative of MAPK activation.

Cells from the fetal bowel were dissociated at E13 and cultured 


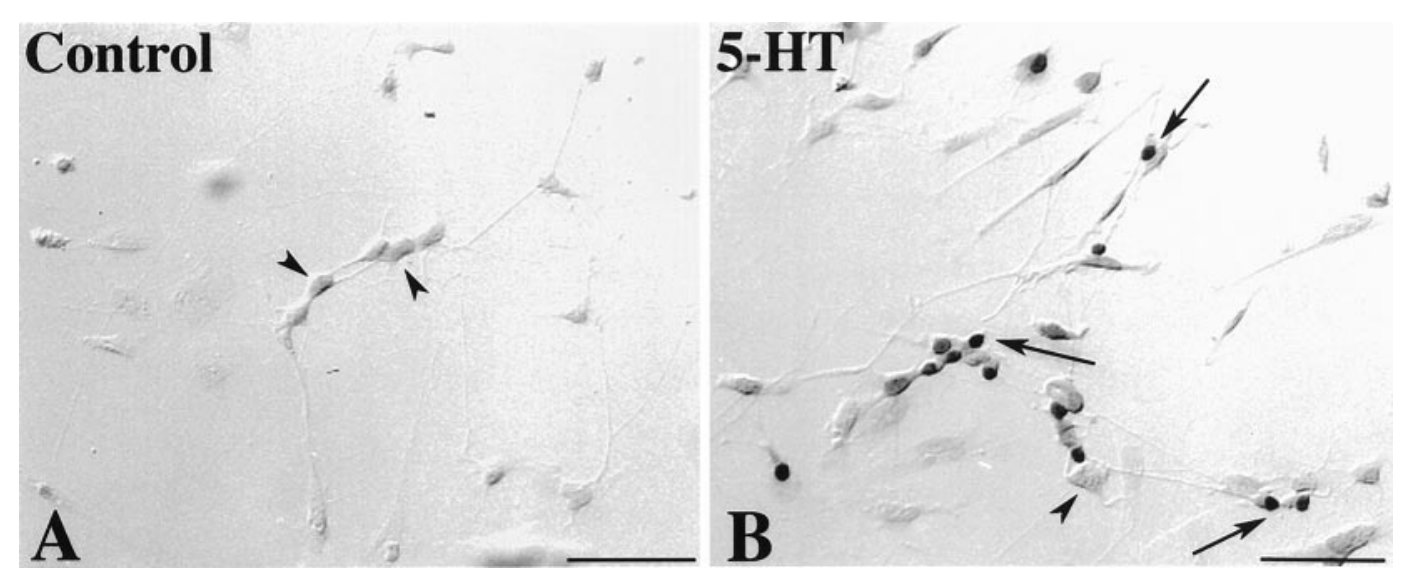

Figure 5. 5-HT activates MAPK in cultures of dissociated cells from fetal gut (E13). Phosphorylated MAPK was demonstrated immunocytochemically. Cells are visualized by interference contrast microscopy. $A$, Control. No nuclear immunoreactivity is demonstrable. Cells with a neuronal morphology $(\triangleright)$ are indicated. $B$, 5-HT $(1 \mu \mathrm{M} ; 45 \mathrm{~min})$. MAPK immunoreactivity $(\rightarrow)$ can be seen in the nuclei of a subset of cells with a neuronal morphology; additional cells with a neuronal morphology are not immunoreactive $(\vec{\nabla})$. Scale bars, $50.0 \mu \mathrm{m}$.

for 3 d. Very little background nuclear p42/44 MAP kinase immunoreactivity could be detected in control cultures (Fig. $5 A$ ). Within $45 \mathrm{~min}$ of the addition of 5 -HT $(1 \mu \mathrm{M})$, however, many cells now displayed nuclear p42/44 MAPK immunoreactivity (Fig. 5B). Most of the cells in the 5-HT-treated cultures with p42/44 MAPK-immunoreactive nuclei, moreover, were process bearing, suggesting that they were in a neuronal or glial lineage. Ritanserin $(1.0 \mu \mathrm{M})$ abolished the response to 5-HT (data not shown). These observations are consistent with the idea that the ability of 5-HT to activate MAPKs in cells cultured from the fetal mouse gut is mediated by a $5-\mathrm{HT}_{2 \mathrm{~B}}$ receptor.

\section{$5-\mathrm{HT}_{2 \mathrm{~B}}$ receptor mRNA is expressed in the fetal mouse gut}

Because ritanserin and SB206553 do not adequately distinguish between $5-\mathrm{HT}_{2 \mathrm{~B}}$ or $5-\mathrm{HT}_{2 \mathrm{C}}$ receptors, studies were performed to determine which subtypes of $5-\mathrm{HT}_{2}$ receptor are actually expressed in the fetal bowel. RNA was isolated from the E16 fetal mouse gut, and RT-PCR was used to detect transcripts encoding members of the $5-\mathrm{HT}_{2}$ receptor family. This analysis suggested that mRNA encoding the 5- $\mathrm{HT}_{2 \mathrm{~A}}$ (Fig. 6A) and 5-HT ${ }_{2 \mathrm{~B}}$ (Fig. 6B) receptors is expressed in the fetal bowel. mRNA encoding the $5-\mathrm{HT}_{2 \mathrm{~A}}$ receptor was also detected in the adult mouse small intestine, stomach, and brain (Fig. 6A). mRNA encoding the $5-\mathrm{HT}_{2 \mathrm{~B}}$ receptor was detected in the adult mouse colon and stomach (Fig. 6B). Little or no mRNA encoding the $5-\mathrm{HT}_{2 \mathrm{~B}}$ receptor could be detected in the adult mouse small intestine or brain. The expression of the $5-\mathrm{HT}_{2 \mathrm{~B}}$ receptor in the stomach was expected and probably reflects the location of this receptor in the smooth muscle of the gastric fundus (Kursar et al., 1992). No mRNA encoding the $5-\mathrm{HT}_{2 \mathrm{C}}$ receptor could be detected with RT-PCR in either the fetal or adult bowel (Fig. $6 C$ ). In contrast, mRNA encoding the $5-\mathrm{HT}_{2 \mathrm{C}}$ receptor was readily detected in the adult mouse brain with the same primers (Fig. $6 C$ ). These observations suggest that $5-\mathrm{HT}_{2 \mathrm{~A}}$ and $5-\mathrm{HT}_{2 \mathrm{~B}}$, but not $5-\mathrm{HT}_{2 \mathrm{C}}$, receptors are expressed in the fetal mouse gut.

\section{Cells that express mRNA encoding 5- $\mathrm{HT}_{2 \mathrm{~B}}$ receptor were located by in situ hybridization in the fetal gut}

In situ hybridization was used to locate cells that express the $5-\mathrm{HT}_{2 \mathrm{~B}}$ receptor in the fetal mouse gut. ${ }^{35} \mathrm{~S}$-labeled sense and antisense riboprobes were synthesized from cDNAs encoding the region between the putative third and sixth transmembrane do- mains of the $5-\mathrm{HT}_{2 \mathrm{~B}}$ receptor. This sequence shares very little identity with the corresponding sequences of the $5-\mathrm{HT}_{2 \mathrm{~A}}$ and $5-\mathrm{HT}_{2 \mathrm{C}}$ receptors. No hybridizing cells could be detected at E13. At E14, however, a small number of cells that hybridized weakly with the antisense but not the sense ${ }^{35}$ S-riboprobe could be detected in ganglia of the small and large intestines (Fig. 7A). The intensity of labeling and the numbers of cells labeled by the antisense ${ }^{35}$ S-riboprobe increased at E15 (Fig. $7 B$ ) and was maximal at E16 (Fig. $7 C, E$ ), so that at this time, virtually every ganglion of the developing myenteric plexus in the fetal stomach and small and large intestine was heavily labeled. In contrast, no cells hybridized with the ${ }^{35} \mathrm{~S}$-sense riboprobe (Fig. $7 D$ ). Cells

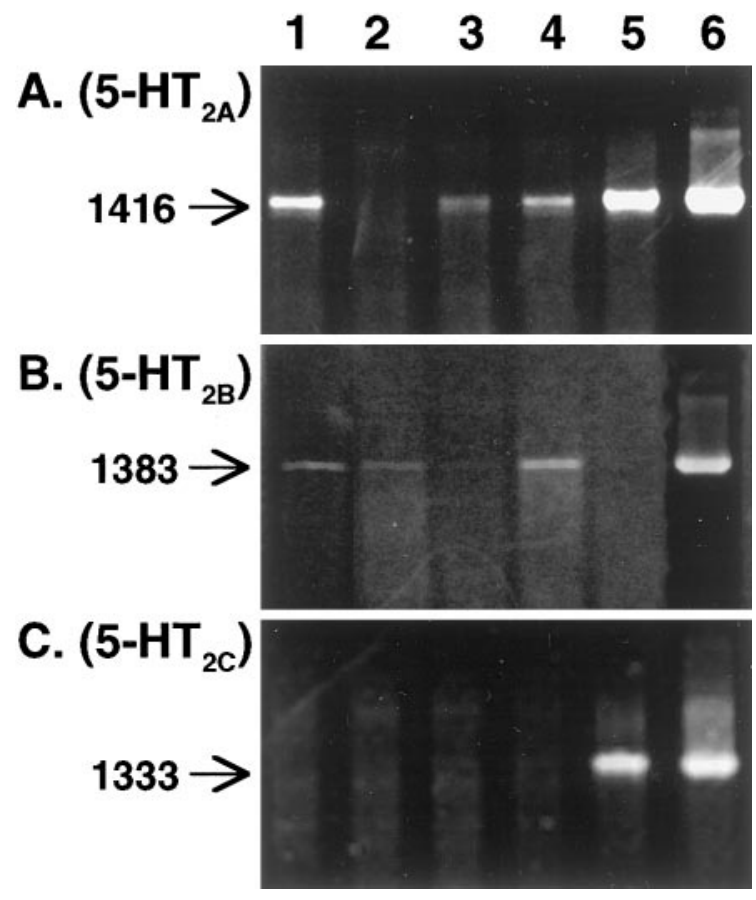

Figure 6. mRNAs encoding $5-\mathrm{HT}_{2 \mathrm{~A}}(A)$ and $5-\mathrm{HT}_{2 \mathrm{~B}}(B)$, but not $5-\mathrm{HT}_{2 \mathrm{C}}(C)$, receptors are expressed in the fetal mouse gut. Receptor expression in fetal and adult bowel was analyzed by RT-PCR. The size of the PCR products is given in base pairs. Lane 1, Fetal gut (E16); lane 2, adult colon; lane 3, adult small intestine; lane 4, stomach; lane 5, brain; lane 6, cDNA from plasmid insert. 

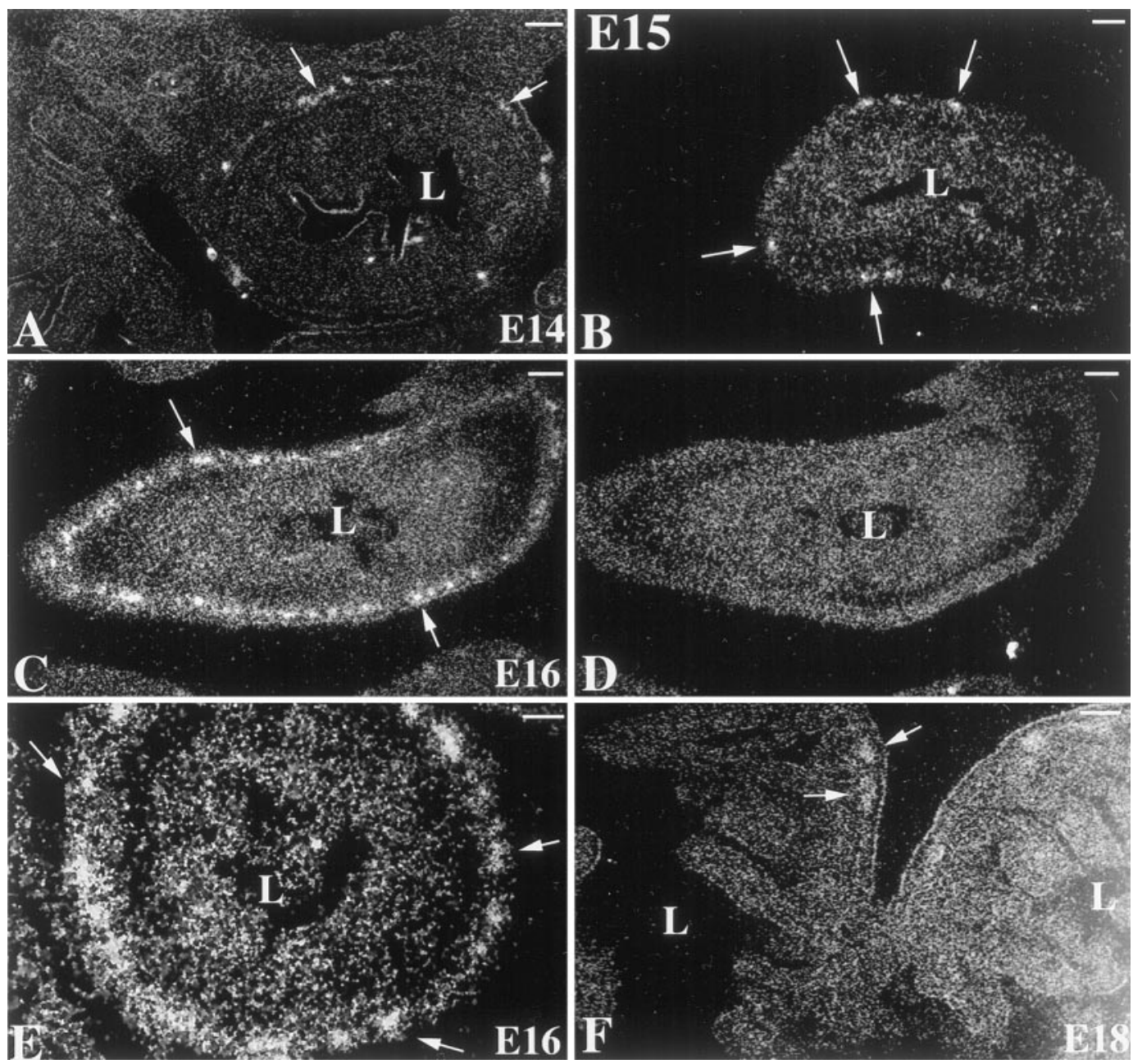

Figure 7. Expression of the 5- $\mathrm{HT}_{2 \mathrm{~B}}$ receptor is developmentally regulated in the ENS. mRNA encoding the 5- $\mathrm{HT}_{2 \mathrm{~B}}$ receptor was located in fetal tissue by in situ hybridization with an antisense ${ }^{35}$ S-riboprobe. As a control, alternate serial sections were hybridized with a sense ${ }^{35}$ S-riboprobe. Sections are visualized by using reflected dark-field illumination. $A$, E14 fetal bowel (antisense riboprobe). $\mathrm{mRNA}_{\mathrm{N}}$ encoding the 5 -HT $\mathrm{H}_{2 \mathrm{~B}}$ receptor is found in scattered ganglia of the primordial myenteric plexus in the outer gut mesenchyme $(\rightarrow)$. The dark-field bright material lining the lumen $(L)$ is caused by the chemographic effects of meconium and is not specific labeling. The section was exposed for 12 weeks. $B$, E15 (antisense riboprobe). The degree of labeling is approximately equal to that seen at E14; however, exposure for only 8 weeks is required to detect mRNA encoding the 5-HT $\mathrm{m}_{2 \mathrm{~B}}$ receptor in primordial myenteric ganglia $(\rightarrow)$. $C$, E16 small intestine (antisense riboprobe). mRNA encoding the 5-HT $\mathrm{H}_{2 \mathrm{~B}}$ receptor is detectable in many myenteric ganglia $(\rightarrow)$ that surround the gut. $D$, E16 control (sense riboprobe). An adjacent section, serial to that illustrated in $C$, is shown. No structures are labeled. $E$, E16 colon (antisense riboprobe). Labeled ganglia $(\rightarrow)$ are even more numerous than in the small intestine at the same age. $F$, E18. Only occasional ganglia are labeled $(\rightarrow)$. Scale bars, $10 \mu \mathrm{m}$.

containing mRNA encoding the $5-\mathrm{HT}_{2 \mathrm{~B}}$ receptor appeared to be most abundant in the colon (Fig. $7 E$ ), where developing myenteric ganglia are more numerous and closely packed than are those in the small intestine (Fig. 7C) or stomach (data not shown). The numbers of cells expressing mRNA encoding the 5-HT $\mathrm{H}_{2 \mathrm{~B}}$ receptor declined rapidly after E16, so that by E18, 5- $\mathrm{HT}_{2 \mathrm{~B}}$ mRNA could be detected only in occasional cells and not in every ganglion of the myenteric plexus (Fig. $7 F$ ). Expression of mRNA encoding the $5-\mathrm{HT}_{2 \mathrm{~B}}$ receptor could not be detected at any time in the submucosal plexus or in the smooth muscle of the fetal intestine.

\section{Cells that express mRNA encoding the $5-\mathrm{HT}_{2 \mathrm{~B}}$ receptor were located by in situ hybridization in the adult gut}

Observations made with in situ hybridization in the fetal bowel suggested that the $5-\mathrm{HT}_{2 \mathrm{~B}}$ receptor might be developmentally regulated. The ${ }^{35} \mathrm{~S}$-labeled antisense riboprobe was thus used to locate cells expressing mRNA encoding the $5-\mathrm{HT}_{2 \mathrm{~B}}$ receptor by in situ hybridization in the adult mouse gut. To investigate the species specificity of the data, we also investigated adult bowel from rat and guinea pig. In the mouse and rat stomach, mRNA encoding the 5- $\mathrm{HT}_{2 \mathrm{~B}}$ receptor was confined to smooth muscle cells in the fundic area (Fig. $8 A, B$ ). Neither the smooth muscle of the gastric corpus or pylorus (Fig. $8 C$ ) nor the skeletal muscle of the esophagus (Fig. $8 D$ ) of the rat or mouse was labeled. The labeled fundic smooth muscle cells were restricted to a band of cells at the periphery of muscle bundles at the junction of the muscularis externa and the connective tissue (Fig. 8A). No hybridization was detected either in neurons or glia in the relatively sparse ganglia of the fundic region. No cells were labeled by the ${ }^{35} \mathrm{~S}$-labeled antisense riboprobe in the adult guinea pig stomach (data not shown).

In contrast to the rat and mouse gastric fundus, mRNA encoding the $5-\mathrm{HT}_{2 \mathrm{~B}}$ receptor was not detected in intestinal smooth 


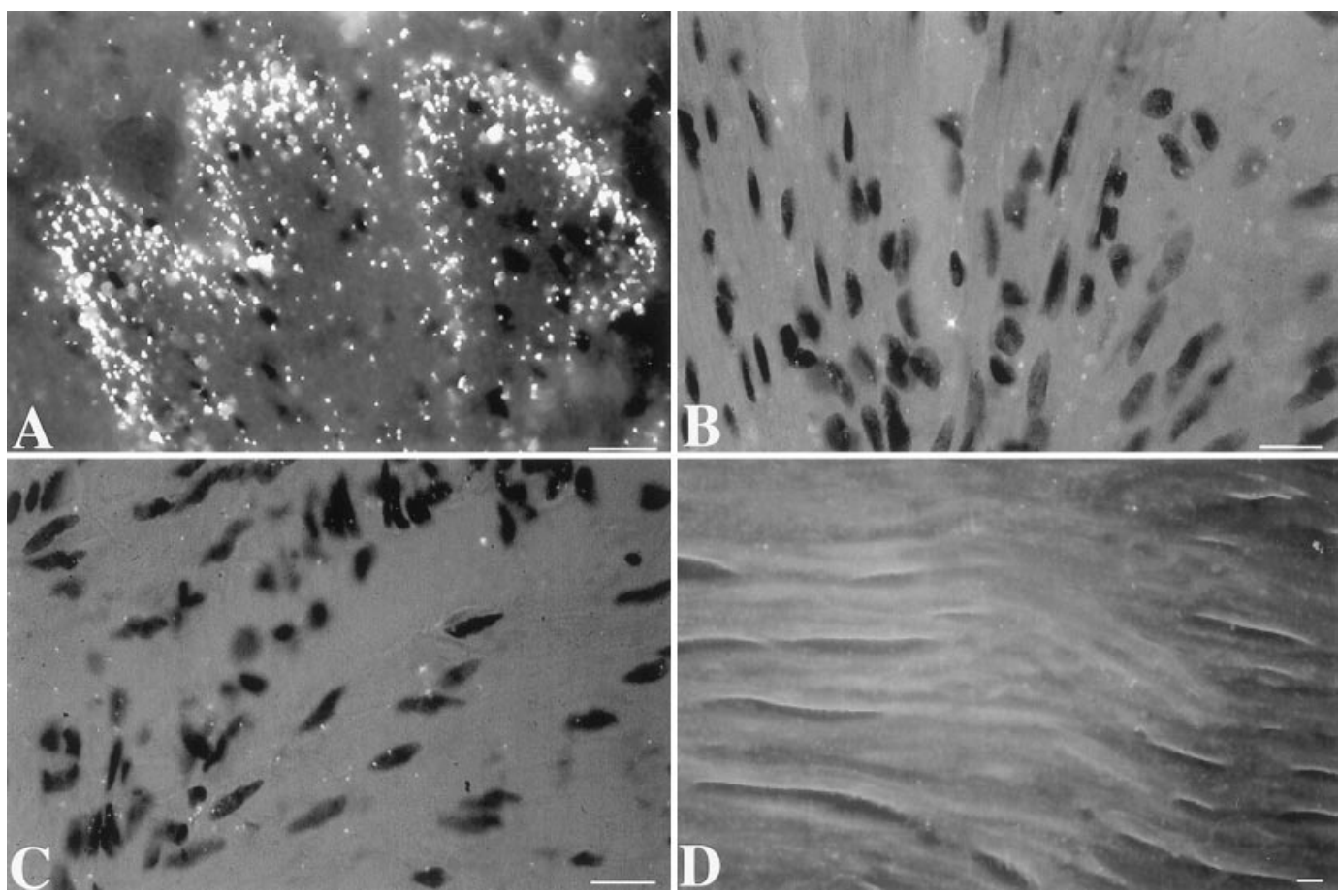

Figure 8. Smooth muscle cells express mRNA encoding the 5- $\mathrm{HT}_{2 \mathrm{~B}}$ receptor only in the fundus of the stomach. $\mathrm{mRNA}$ encoding the 5-HT $2 \mathrm{~B}$ receptor was located in the adult rat stomach by in situ hybridization with an antisense ${ }^{35}$ S-riboprobe. Sections are visualized by using a combination of reflected dark-field and bright-field illumination. $A$, Fundus (antisense riboprobe). mRNA encoding the 5-HT ${ }_{2 \mathrm{~B}}$ receptor is concentrated in cells located at the periphery of muscle bundles. $B$, Fundus, control (sense riboprobe). An adjacent section, serial to that illustrated in $A$, is shown. No structures are labeled. $C$, Corpus (antisense riboprobe). No structures are labeled. $D$, Esophagus (antisense riboprobe). No structures are labeled. Scale bars, $20 \mu \mathrm{m}$.

muscle. Instead, intestinal expression of the $5-\mathrm{HT}_{2 \mathrm{~B}}$ receptor was confined to a small subset of myenteric neurons (compare Fig. $9 A$ with $B$, control). The small intestinal location of mRNA encoding the $5-\mathrm{HT}_{2 \mathrm{~B}}$ receptor was essentially the same in the rat (Fig. $9 A, B$ ), mouse (Fig. $9 C-F$ ), and guinea pig (data not shown). The number of $5-\mathrm{HT}_{2 \mathrm{~B}}$-expressing neurons increased proximodistally. The expression of $5-\mathrm{HT}_{2 \mathrm{~B}}$ mRNA was also observed in the crypt epithelium of the mouse small intestine (compare Fig. $9 C, E$ with $D, F$, controls).

\section{Myenteric ganglia of the fetal and adult mouse gut contain $5-\mathrm{HT}_{2 \mathrm{~B}}$-immunoreactive cells}

$5-\mathrm{HT}_{2 \mathrm{~B}}$ receptor immunoreactivity was demonstrable in neurons of the myenteric plexus of the small and large intestines of E15 fetal mice (Fig. 10). At this age, virtually every myenteric ganglion contained $5-\mathrm{HT}_{2 \mathrm{~B}}$ receptor immunoreactivity (Fig. 10A,B). The 5- $\mathrm{HT}_{2 \mathrm{~B}}$ immunoreactivity of most of the labeled myenteric neurons appeared to be concentrated at the periphery of the cells (Fig. 10C). 5- $\mathrm{HT}_{2 \mathrm{~B}}$-immunoreactive cells were less abundant in adult than in fetal ganglia (Fig. $10 D$ ). No $5-\mathrm{HT}_{2 \mathrm{~B}}$ immunoreactivity was observed in the submucosal plexus or in the smooth muscle of the mouse intestine.

\section{Neurons developing in cultures of cells dissociated from fetal mouse intestine are $5-\mathrm{HT}_{2 \mathrm{~B}}$ immunoreactive}

Both polyclonal and monoclonal antibodies to the $5-\mathrm{HT}_{2 \mathrm{~B}}$ receptor labeled cells in cultures of dissociated E14 fetal mouse gut (Fig. 11). Double-label immunocytochemistry revealed that most, but not all, of the $5-\mathrm{HT}_{2 \mathrm{~B}}$-immunoreactive cells coexpressed PGP9.5 immunoreactivity. Patches of $5-\mathrm{HT}_{2 \mathrm{~B}}$ immunoreactivity were found on the cell bodies of these neurons and also on their varicose neurites. The perikarya of most of the doubly labeled neurons were strongly PGP9.5 immunoreactive; however, 5- $\mathrm{HT}_{2 \mathrm{~B}}$ receptors were also found on occasional cells with only weak PGP9.5 immunoreactivity. The cells with coincident $5-\mathrm{HT}_{2 \mathrm{~B}} /$ PGP9.5 immunoreactivity represented a subset of the PGP9.5immunoreactive cell population. The $5-\mathrm{HT}_{2 \mathrm{~B}}$-immunoreactive cells that did not express PGP9.5 immunoreactivity were located close to the neurons and thus might have been crest-derived precursors that had not yet acquired the neural marker or glia.

\section{DISCUSSION}

The current study supports the tested hypothesis that 5-HT promotes the differentiation of enteric neurons by stimulating a developmentally regulated receptor expressed by crest-derived neuronal progenitors. First, the following observations suggest that stimulation of 5- $\mathrm{HT}_{2 \mathrm{~B}}$ receptors in vitro enhances the enteric neuronal development: (1) Both 5-HT and the 5- $\mathrm{HT}_{2}$ agonist DOI promote in vitro differentiation of enteric neurons; the effect of 5-HT is blocked by the $5-\mathrm{HT}_{1 / 2}$ antagonist methysergide. (2) Ritanserin, a pan-5- $\mathrm{HT}_{2}$ antagonist, which lacks activity against $5-\mathrm{HT}_{1}$ receptors, totally abolishes responses to 5-HT and DOI, whereas an equal concentration of the $5-\mathrm{HT}_{2 \mathrm{~A}}$-selective antagonist ketanserin does not. (3) The 5- $\mathrm{HT}_{2 \mathrm{~B} / 2 \mathrm{C}}$ antagonist SB206553, which has little antagonistic activity at $5-\mathrm{HT}_{1}$ or $5-\mathrm{HT}_{2 \mathrm{~A}}$ sites (Audia et al., 1996; Kennett et al., 1996), blocks the promotion of neuronal differentiation by 5-HT. (4) mRNA encoding the $5-\mathrm{HT}_{2 \mathrm{~B}}$ receptor is expressed in the fetal bowel, whereas that encoding the $5-\mathrm{HT}_{2 \mathrm{C}}$ receptor, which might also have been affected by ritanserin and SB206553, is not. These data do not definitively eliminate an additional role for the $5-\mathrm{HT}_{2 \mathrm{~A}}$ receptor in development.

Second, evidence that $5-\mathrm{HT}_{2 \mathrm{~B}}$ receptors are expressed by crest- 

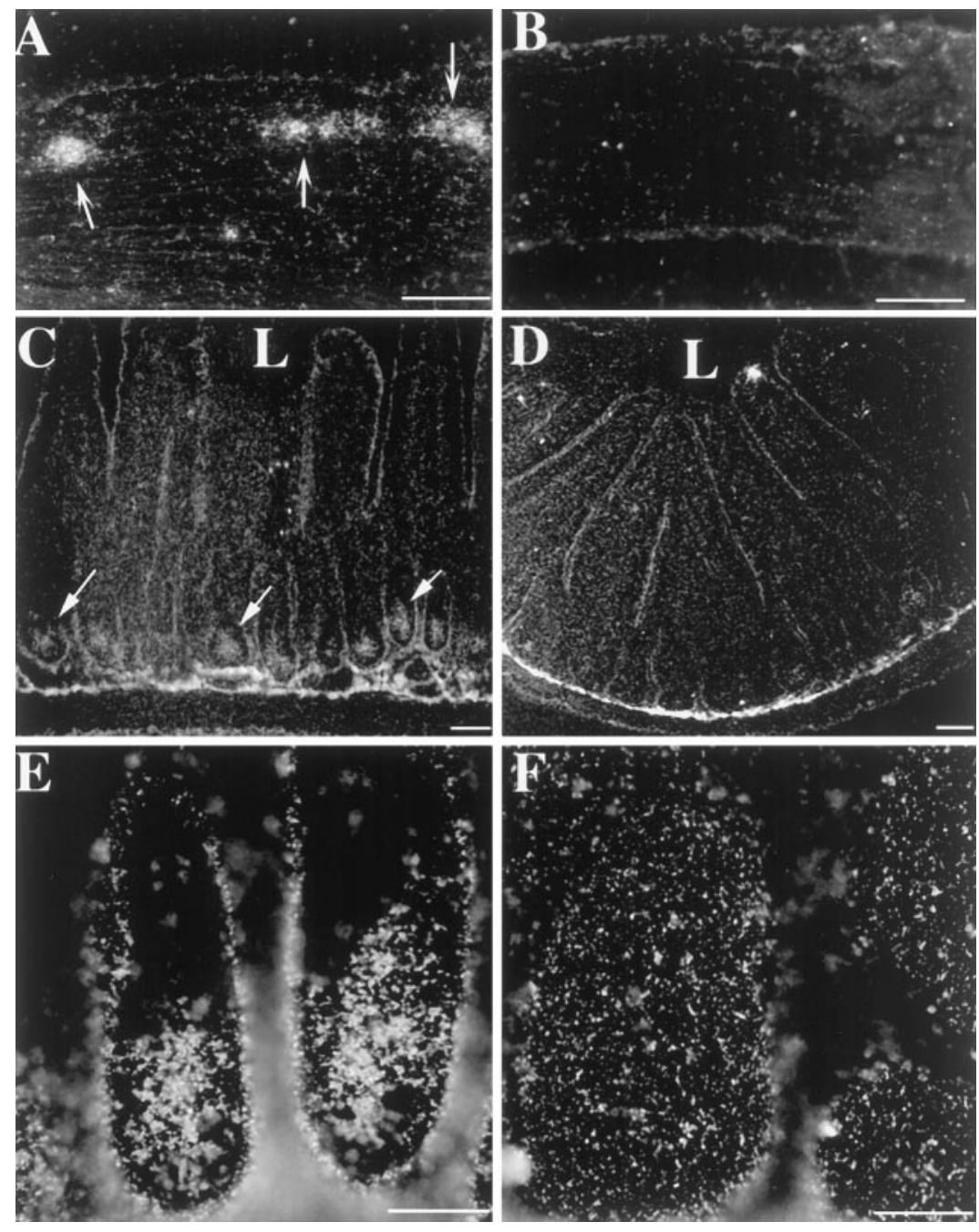

Figure 9. mRNA encoding the $5-\mathrm{HT}_{2 \mathrm{~B}}$ receptor is expressed in intestinal neurons. In situ hybridization with an ${ }^{35}$ S-riboprobe. $A$, Rat colon (antisense riboprobe). mRNA encoding the $5-\mathrm{HT}_{2 \mathrm{~B}}$ receptor is concentrated in cells in the myenteric ganglia. $B$, Rat colon, control (sense riboprobe). $C, E$, Mouse ileum sections (antisense riboprobe). mRNA encoding the 5- $\mathrm{HT}_{2 \mathrm{~B}}$ receptor is found in crypt epithelial cells $(\rightarrow) . D, F$, Mouse ileum sections, control (sense riboprobe). $L$, Lumen. Scale bars: $A-D, 50 \mu \mathrm{m} ; E, F, 20 \mu \mathrm{m}$.

derived neural precursors included the following: (1) 5-HT and DOI promote neuronal development when they are added to cultures of crest-derived precursors isolated by immunoselection with antibodies to $\mathrm{p} 75^{\mathrm{NTR}}$, and the effects of both agonists are blocked by SB206553. (2) mRNA encoding the 5-HT $2 \mathrm{~B}$ receptor was detected by RT-PCR in isolated intestinal ganglia (FioricaHowells and Gershon, 1995). (3) mRNA encoding the 5- $\mathrm{HT}_{2 \mathrm{~B}}$ receptor (demonstrated by in situ hybridization) is developmentally regulated and abundant in primordial (E15-E16) myenteric ganglia. (4) $5-\mathrm{HT}_{2 \mathrm{~B}}$ immunoreactivity was found in many developing enteric neurons. (5) $5-\mathrm{HT}_{2 \mathrm{~B}}$-immunoreactive cells present in cultures of fetal gut coexpress PGP9.5, a marker for cells specified as neuronal. The weak PGP9.5 immunoreactivity (which might just have been acquired) in some of the doubly labeled cells is consistent with the possibility that expression of $5-\mathrm{HT}_{2 \mathrm{~B}}$ receptors precedes that of PGP9.5.

The $5-\mathrm{HT}_{2 \mathrm{~B}}$ receptor was originally known as the "fundus receptor," because it was thought to be unique to muscle cells of the fundic (rumen) region of the rat and mouse stomachs (Baez et al., 1990; Foguet et al., 1992a,b; Kursar et al., 1992; Wang et al., 1993). The 5- $\mathrm{HT}_{2 \mathrm{~B}}$ receptor, however, was found to be expressed, not only by the fundic muscle, but also by intestinal neurons. The muscular distribution of mRNA encoding the $5-\mathrm{HT}_{2 \mathrm{~B}}$ receptor was strikingly limited to the fundic regions of the rat and mouse stomachs. The $5-\mathrm{HT}_{2 \mathrm{~B}}$-expressing muscle cells of the rat and mouse stomachs, moreover, were restricted to the periphery of muscle bundles. This localization is compatible with the idea that the $5-\mathrm{HT}_{2 \mathrm{~B}}$ receptor is selectively expressed by that subset of muscle cells that is innervated. Because enteric smooth muscle cells are electrically coupled, the effects of stimulating $5-\mathrm{HT}_{2 \mathrm{~B}}$ receptors on innervated cells could be transmitted to the noninnervated cells deep in muscle bundles.

It is difficult to envision a role for a receptor expressed, as is the $5-\mathrm{HT}_{2 \mathrm{~B}}$ in adults, only on rare cells in a minority of enteric ganglia. Moreover, although the electrophysiological responses of enteric neurons to 5-HT have been thoroughly characterized, none have been found to be mediated by a member of the $5-\mathrm{HT}_{2}$ receptor family (Gershon, 1995, 1999; Galligan, 1996). The timing of the developmental regulation of the $5-\mathrm{HT}_{2 \mathrm{~B}}$ receptor implies that its function is likely to be more significant during the formation of the ENS, when the receptor is abundant, than in adult life, when it is rare. Conceivably, stimulation of enteric neuronal $5-\mathrm{HT}_{2 \mathrm{~B}}$ receptors does not lead to a change in membrane potential but mediates a trophic function of 5-HT, even in mature animals. The rare adult ganglion cells that express the $5-\mathrm{HT}_{2 \mathrm{~B}}$ receptor might represent a small set of 5-HT-responsive neuronal progenitors that persist in the adult bowel or mature neurons that retain a vestigial fetal receptor.

The $5-\mathrm{HT}_{2}$ receptor family has been linked previously to the regulation of growth and/or differentiation. 5-HT stimulates mi- 


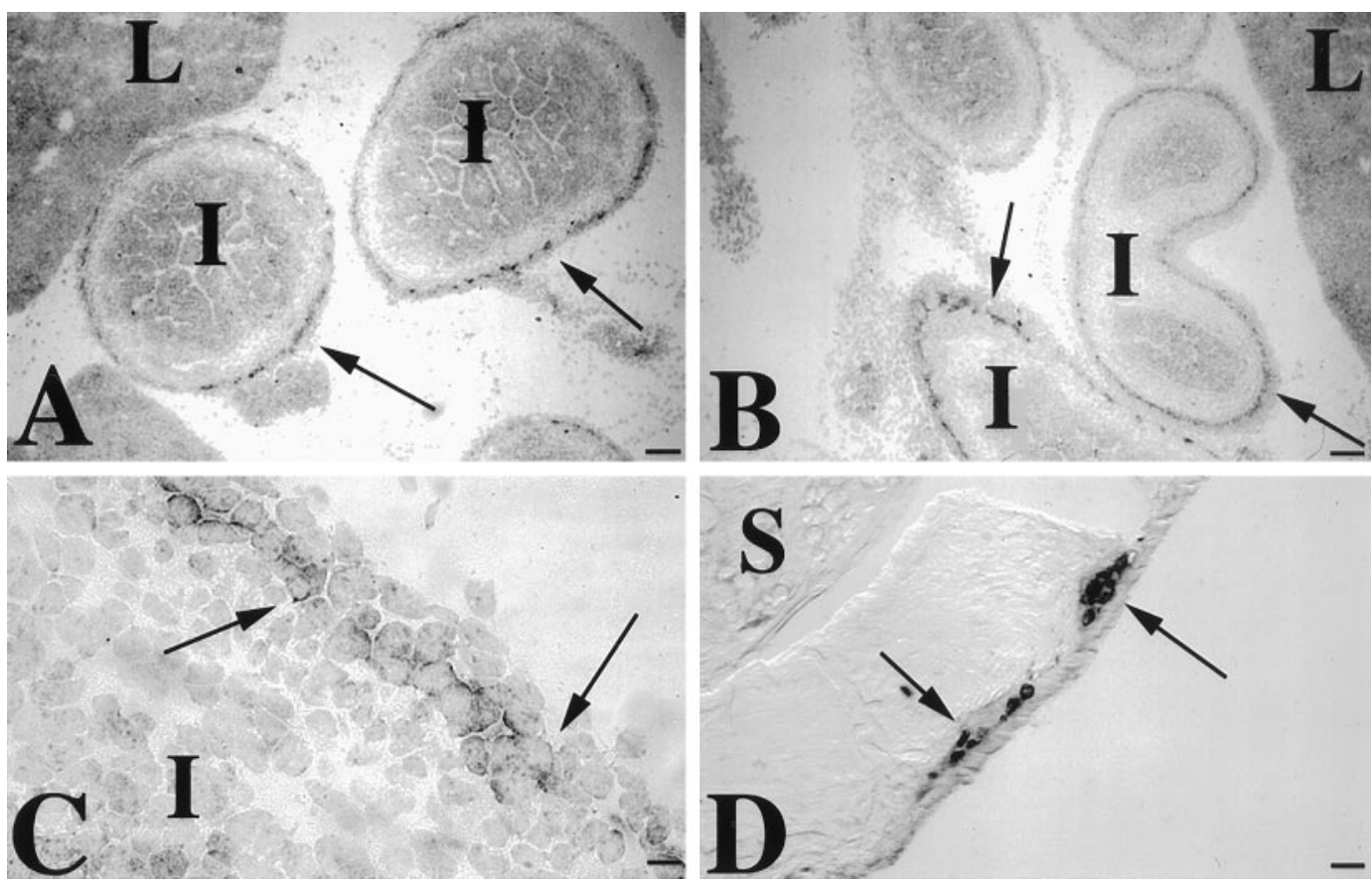

Figure 10. 5- $\mathrm{HT}_{2 \mathrm{~B}}$ immunoreactivity is present in neurons of the fetal and adult mouse intestine. $A, B$, E15 small intestinal loops $(I)$ are shown. Note that immunoreactive myenteric ganglia $(\rightarrow)$ surround the cross sections of gut. $C, 5-\mathrm{HT}_{2 \mathrm{~B}}$ immunoreactivity is concentrated on ganglion cell surfaces $(\rightarrow)$. Most myenteric cells are 5- $\mathrm{HT}_{2 \mathrm{~B}}$ immunoreactive. $D$, Adult stomach is shown. 5- $\mathrm{HT}_{2 \mathrm{~B}}$-immunoreactive neurons are present in myenteric ganglia. The $\rightarrow$ symbols point to some of the positive ganglia. $L$, Liver; $S$, stomach. Scale bars: $A, B, 100 \mu \mathrm{m} ; C, 10 \mu \mathrm{m} ; D, 25 \mu \mathrm{m}$.

Figure 11. A subset of PGP9.5-immunoreactive neurons expresses $5-\mathrm{HT}_{2 \mathrm{~B}}$ immunoreactivity in a culture of fetal bowel dissociated at E14. Laser-scanning confocal microscopic image. The immunoreactivity of PGP9.5 (FITC) appears green and that of $5-\mathrm{HT}_{2 \mathrm{~B}}$ receptors appears red $(\mathrm{Cy} 3)$; doubly labeled structures are yellow. Clusters of 5- $\mathrm{HT}_{2 \mathrm{~B}}$ immunoreactivity are found on PGP-immunoreactive cell bodies (white $\rightarrow$ ) and the varicosities of their neurites (blue $\rightarrow$ ). Occasional 5- $\mathrm{HT}_{2 \mathrm{~B}}$-immunoreactive cells are weakly immunostained with antibodies to PGP9.5 $($ pink $\rightarrow$ ). Rare cells, located close to neurons, express $5-\mathrm{HT}_{2 \mathrm{~B}}$ but not PGP9.5 immunoreactivity. Scale bar, $10 \mu \mathrm{m}$.

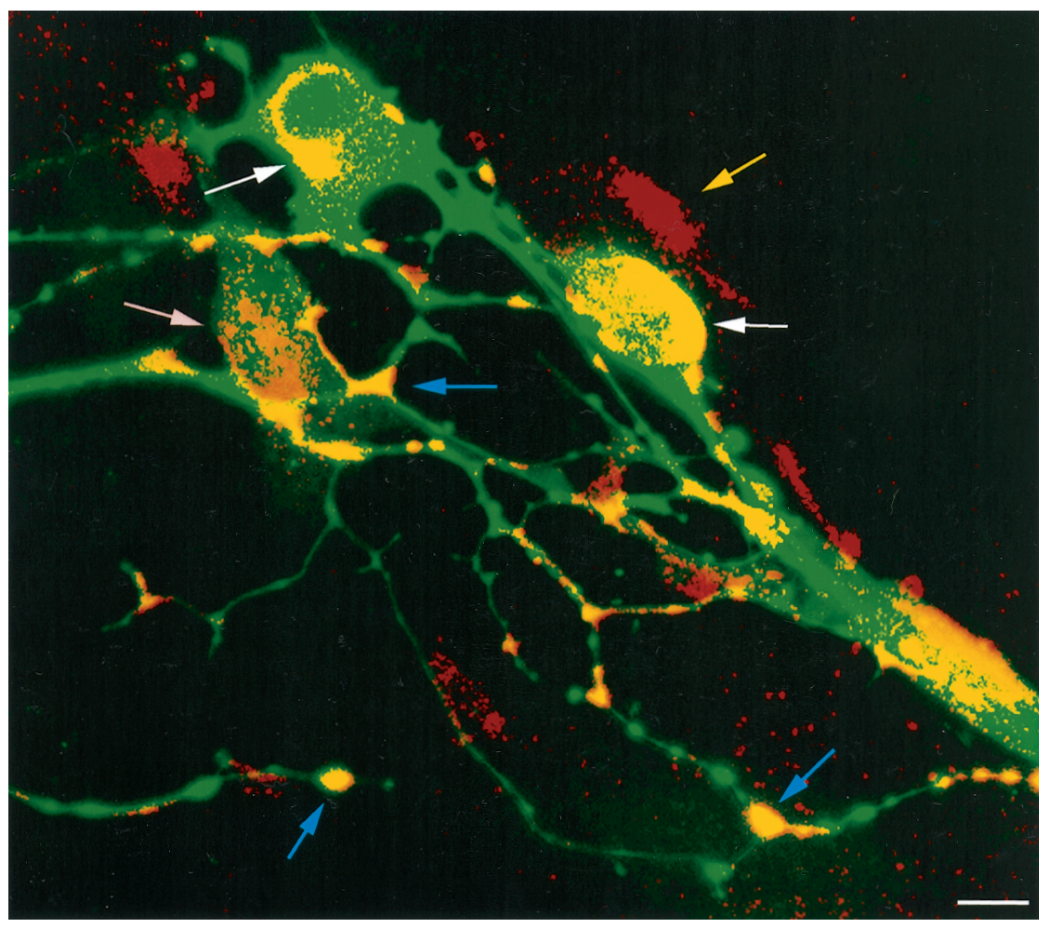

tosis and differentiation when it is added to transfected fibroblasts that express either the 5- $\mathrm{HT}_{2 \mathrm{~B}}$ (Choi et al., 1994; Launay et al., 1996 ) or the $5-\mathrm{HT}_{2 \mathrm{C}}$ (Julius et al., 1989) receptor. In fact, transfected fibroblasts that express the $5-\mathrm{HT}_{2 \mathrm{~B}}$ receptor can be transformed by 5 -HT or DOI in vitro, and the resulting foci give rise to tumors when transplanted into nude mice (Launay et al., 1996). Growth of the foci in vitro and the tumors in vivo is inhibited by ritanserin. The $5-\mathrm{HT}_{2 \mathrm{~B}}$ receptor has also been shown to affect the development of cranial crest-derived ectomesenchyme (Choi et al., 1997). The developmental effects of the 5-HT $2 \mathrm{~B}$ receptor found in the present investigation, therefore, are not unprecedented. In fact, a transiently catecholaminergic cell line, 1C11, that expresses first 5-HT, then $5-\mathrm{HT}_{2 \mathrm{~B}}$, and finally $5-\mathrm{HT}_{2 \mathrm{~A}}$ receptors has been reported (Kellermann et al., 1996). This sequence resembles that found in the developing ENS.

In addition to cells in a neuronal lineage, epithelial cells in 
intestinal crypts were found to express the 5- $\mathrm{HT}_{2 \mathrm{~B}}$ receptor. Crypt epithelial cells also represent a site where $5-\mathrm{HT}_{2 \mathrm{~B}}$ receptors are likely to affect growth and/or differentiation. The crypts of the gut contain a self-renewing stem cell population that continually differentiates throughout life to replace the cells that line the luminal surface of the small and large intestines (Roth et al., 1991). 5-HT stimulates the proliferation of both normal (Tutton, 1974) and neoplastic (Tutton and Barkla, 1980) intestinal crypt cells. Intestinal epithelial cells, moreover, have been shown to express a $5-\mathrm{HT}_{2}$ receptor (Siriwardena et al., 1993). It is thus possible that the $5-\mathrm{HT}_{2 \mathrm{~B}}$ receptor is linked to cell growth and/or differentiation in both neurectodermal and endodermal derivatives of the gut.

Stimulation of $5-\mathrm{HT}_{2 \mathrm{~B}}$ receptors, spontaneously expressed by Mastomys tumor cells, or those expressed by transfected fibroblasts induces a rapid and transient activation of p21 ras and MAPK (Launay et al., 1996). In the current study, 5-HT was also found to induce phosphorylation and nuclear translocation of MAPK in vitro. The responding cells displayed a neuronal morphology. The activation of MAPK by 5-HT, like 5-HT's ability to promote the development of enteric neurons, was blocked by ritanserin. It is thus possible that $5-\mathrm{HT}_{2 \mathrm{~B}}$-related effects on the development of enteric neurons are dependent on the activation of MAPK. Activation of MAPK could increase the number of neurons in vitro by exerting (1) a mitogenic effect on proliferating neuronal precursors, (2) a differentiating effect on postmitotic progenitors causing them to exhibit neuronal properties, and (3) a survival effect on existing neurons. Although preliminary experiments with bromodeoxyuridine did not reveal a mitogenic action of 5-HT on cultured enteric crest-derived cells, the current data do not permit a choice to be made between these alternatives.

The appearance of the $5-\mathrm{HT}_{2 \mathrm{~B}}$ receptor coincides with the end of the period during which serotonergic neurons are born and with the onset of the birthdays of mash-1-independent neurons (Pham et al., 1991). The developmental regulation of the $5-\mathrm{HT}_{2 \mathrm{~B}}$ receptor is thus appropriate for it to mediate serotonergic effects on the development of the late-developing, mash-1-independent set of enteric neurons. The observation that synapses are formed between early-developing enteric neurons and still-dividing neuronal precursors in the fetal myenteric plexus (Gershon et al., 1981) is consistent with the concept that a neurotransmitter influences neuronal development. Because 5-HT-containing EC cells, as well as serotonergic neurons, are present when $5-\mathrm{HT}_{2 \mathrm{~B}}$ receptors appear (Branchek and Gershon, 1989), there are two potential sources of 5-HT in the bowel during the period of time when the $5-\mathrm{HT}_{2 \mathrm{~B}}$ receptor is expressed in the gut. The gut is well equipped to inactivate 5-HT because the 5-HT transporter is expressed both in serotonergic neurons and in the mucosal epithelium (Wade et al., 1996; Chen et al., 1998).

Observations made in the present study are compatible with the hypotheses that 5-HT acts on crest-derived cells to promote the development of enteric neurons and that a developmentally regulated receptor, $5-\mathrm{HT}_{2 \mathrm{~B}}$, is responsible for this effect. The timing and the pattern of the expression of this receptor in the bowel, as well as the development of enteric sources of 5-HT, suggest that late-developing (mash-1-independent) neurons may be in situ targets of the growth factor-like actions of 5-HT. The ability of a neurotransmitter/paracrine factor, like 5-HT, to affect enteric neuronal development provides a potential mechanism by which the experience of the immature gut could influence the nature of the ENS that ultimately develops in a mature animal. By affecting the activity of enteric serotonergic neurons and/or mucosal EC cells, the luminal content might determine the number, or even the phenotypic composition (Lavdas et al., 1997), of the neurons of the adult ENS. In mice, new neurons continue to be added to the ENS for at least the first 3 postnatal weeks (Pham et al., 1991). The equivalent period has not been determined for humans, but the differences between mice and humans in size, period of gestation, and life span suggest that new neurons are probably added to the postnatal human gut for much more than 3 weeks. The development of the human ENS might thus be expected to be especially susceptible to an activity-dependent influence on its development.

\section{REFERENCES}

Audia JE, Evrard DA, Murdoch GR, Droste JJ, Nissen JS, Schenk KW, Fludzinski P, Lucaites VL, Nelson DL, Cohen ML (1996) Potent, selective, tetrahydro- $\beta$-corboline antagonists of the 5 -HT2B $\left(5-\mathrm{HT}_{2 \mathrm{~B}}\right)$ contractile receptor in the rat stomach fundus. J Med Chem 39:2773-2780.

Azmitia EC, Dolan K, Whitaker-Azmitia PM (1990) S100b, but not NGF, EGF, insulin or calmodulin is a CNS serotonergic growth factor. Brain Res 516:354-356.

Baez M, Yu L, Cohen ML (1990) Pharmacological and molecular evidence that the contractile response to serotonin in rat stomach fundus is not mediated by activation of the 5-hydroxytryptamine ${ }_{1 \mathrm{C}}$ receptor. J Pharmacol Exp Ther 38:31-37.

Baynash AG, Hosoda K, Giaid A, Richardson JA, Emoto N, Hammer RE, Yanagisawa M (1994) Interaction of endothelin-3 with endothelin-B receptor is essential for development of epidermal melanocytes and enteric neurons. Cell 79:1277-1285.

Blaugrund E, Pham TD, Tennyson VM, Lo L, Sommer L, Anderson DJ, Gershon MD (1996) Distinct subpopulations of enteric neuronal progenitors defined by time of development, sympathoadrenal lineage markers, and Mash-1-dependence. Development 122:309-320.

Branchek TA, Gershon MD (1989) Time course of expression of neuropeptide Y, calcitonin gene related peptide, and NADPH diaphorase activity in neurons of the developing murine bowel and the appearance of 5-hydroxytryptamine in mucosal enterochromaffin cells. J Comp Neurol 285:262-273.

Chalazonitis A, Rothman TP, Chen J, Lamballe F, Barbacid M, Gershon MD (1994) Neurotrophin-3 induces neural crest-derived cells from fetal rat gut to develop in vitro as neurons or glia. J Neurosci 14:6571-6584.

Chalazonitis A, Tennyson VM, Kibbey MC, Rothman TP, Gershon MD (1997) The $\alpha$-1 subunit of laminin-1 promotes the development of neurons by interacting with LBP110 expressed by neural crest-derived cells immunoselected from the fetal mouse gut. J Neurobiol 33:118-138.

Chalazonitis A, Rothman TP, Chen J, Vinson EN, MacLennan AJ, Gershon MD (1998a) Promotion of the development of enteric neurons and glia by neuropoietic cytokines: interactions with neurotrophin-3. Dev Biol 198:343-365.

Chalazonitis A, Rothman TP, Chen J-X, Gershon MD (1998b) Agedependent differences in the effects of GDNF and NT-3 on the development of neurons and glia from neural crest-derived precursors immunoselected from the fetal rat gut: expression of GFRa in vitro and in vivo. Dev Biol 204:385-406.

Chen J-X, Pan H, Rothman TP, Wade PR, Gershon MD (1998) Guinea pig 5-HT transporter: cloning, expression, distribution and function in intestinal sensory reception. Am J Physiol 275:G433-G448.

Choi D-S, Maroteaux L (1996) Immunohistochemical localisation of the serotonin $5-\mathrm{HT}_{2 \mathrm{~B}}$ receptor in mouse gut, cardiovascular system, and brain. FEBS Lett 391:45-51.

Choi D-S, Colas J-F, Kellermann O, Loric S, Launay J-M, Rosay P, Maroteaux L (1994) The mouse 5- $\mathrm{HT}_{2 \mathrm{~B}}$ receptor: possible involvement in trophic functions of serotonin. Cell Mol Biol 40:403-411.

Choi D-S, Ward SJ, Messaddeq N, Launay J-M, Maroteaux L (1997) $5-\mathrm{HT}_{2 \mathrm{~B}}$ receptor-mediated serotonin morphogenetic functions in mouse cranial neural crest and myocardiac cells. Development 124:1745-1755.

Chomczynski P, Sacchi N (1987) Single-step method of RNA isolation by acid guanidinium thiocyanate-phenol-chloroform extraction. Anal Biochem 162:156-159. 
Cooke HJ, Sidhu M, Wang Y-Z (1997) 5-HT activates neural reflexes regulating secretion in the guinea-pig colon. Neurogastroenterol Motil 9:181-186.

Fiorica-Howells E, Gershon MD (1995) The 5-HT ${ }_{2 \mathrm{~B}}$ receptor: molecular cloning, identification of a splice variant, and localization of mRNA in smooth muscle and neurons of the guinea pig and rat intestines. Soc Neurosci Abstr 21:774.

Foguet M, Hoyer D, Pardo LA, Parekh A, Kluxen FW, Kalkman HO, Stümer W, Lübbert H (1992a) Cloning and functional characterization of the rat stomach fundus serotonin receptor. EMBO J 11:3481-3487.

Foguet M, Nguyen H, Le H, Lübbert H (1992b) Structure of the mouse fundus serotonin receptor genes. NeuroReport 3:345-348.

Fraser SE, Bronner-Fraser M (1991) Migrating neural crest cells in the trunk of the avian embryo are multipotent. Development 112:913-920.

Furness JB, Costa M (1987) The enteric nervous system, pp 65-69. New York: Livingstone.

Galligan JJ (1996) Electrophysiological studies of 5-hydroxytryptamine receptors on enteric neurons. Behav Brain Res 73:199-201.

Gershon MD (1995) Localization and neurochemical aspects of serotonin in the gut. In: Serotonin and gastrointestinal function (Gaginella TS, Galligan JJ, eds), pp 11-31. Boca Raton, FL: CRC.

Gershon MD (1997) Genes and lineages in the formation of the enteric nervous system. Curr Opin Neurobiol 7:101-109.

Gershon MD (1998) Genes, lineages, and tissue interactions in the development of the enteric nervous system. Am J Physiol 275:G869-G873.

Gershon MD (1999) Roles played by 5-hydroxytryptamine in the physiology of the bowel. Aliment Pharmacol Ther 13[Suppl 2]:15-30.

Gershon MD, Sherman D, Gintzler A (1981) An ultrastructural analysis of the developing enteric nervous system of the guinea pig small intestine. J Neurocytol 10:271-296.

Gershon MD, Kirchgessner AL, Wade PR (1994) Functional anatomy of the enteric nervous system. In: Physiology of the gastrointestinal tract, Third Edition (Johnson LR, Alpers DH, Jacobson ED, Walsh JH, eds), pp 381-422. New York: Raven.

Hearn CJ, Murphy M, Newgreen D (1998) GDNF and ET-3 differentially modulate the numbers of avian enteric neural crest cells and enteric neurons in vitro. Dev Biol 197:93-105.

Huber LJ, Chao MV (1995) Mesenchymal and neuronal cell expression of the p75 neurotrophin gene occur by different mechanisms. Dev Biol 167:237-238.

Ito K, Sieber-Blum M (1993) Pluripotent and developmentally restricted neural-crest-derived cells in posterior visceral arches. Dev Biol 156:191-200.

Ito K, Morita T, Sieber-Blum M (1993) In vitro analysis of mouse neural crest development. Dev Biol 157:517-525.

Julius D, Livelli TJ, Jessell TM, Axel R (1989) Ectopic expression of the serotonin $1 \mathrm{c}$ receptor and the triggering of malignant transformation. Science 244:1057-1062.

Kellermann O, Loric S, Maroteaux L, Launay JM (1996) Sequential onset of three 5-HT receptors during the 5-hydroxytryptaminergic differentiation of the murine $1 \mathrm{C} 11$ cell line. $\mathrm{Br} \mathrm{J}$ Pharmacol 118:1161-1170.

Kennett GA, Wood MD, Bright F, Cilia J, Piper DC, Gager T, Thomas D, Baxter GS, Forbes IT, Ham P, Blackburn TP (1996) In vitro and in vivo profile of SB 206553, a potent $5-\mathrm{HT}_{2 \mathrm{C}} / 5-\mathrm{HT}_{2 \mathrm{~B}}$ receptor antagonist with anxiolytic-like properties. Br J Pharmacol 117:427-434.

Kursar JD, Nelson DJ, Wainscott DB, Cohen ML, Baez M (1992) Molecular cloning, functional expression, and pharmacological characterization of a novel serotonin receptor (5-hydroxytryptamine ${ }_{2 \mathrm{~F}}$ ) from rat stomach fundus. Mol Pharmacol 42:549-557.

Lauder JM (1988) Neurotransmitters as morphogens. Prog Brain Res 73:365-387.

Lauder JM (1993) Neurotransmitters as growth regulatory signals: role of receptors and second messengers. Trends Neurosci 16:233-240.

Lauder JM, Krebs H (1978) Serotonin as a differential signal in early neurogenesis. Dev Neurosci 1:15-30.

Launay J-M, Birraux G, Bondoux D, Callebert J, Choi D-S, Loric S, Maroteaux L (1996) Ras involvement in signal transduction by the serotonin 5- $\mathrm{HT}_{2 \mathrm{~B}}$ receptor. J Biol Chem 271:3141-3147.

Lavdas AA, Blue ME, Lincoln J, Parnavelas JG (1997) Serotonin promotes the differentiation of glutamate neurons in organotypic slice cultures of the developing cerebral cortex. J Neurosci 17:7872-7880.

Le Douarin NM, Teillet MA (1973) The migration of neural crest cells to the wall of the digestive tract in avian embryo. J Embryol Exp Morphol 30:31-48.

Le Douarin NM, Teillet MA (1974) Experimental analysis of the migration and differentiation of neuroblasts of the autonomic nervous system and of neurectodermal mesenchymal derivatives, using a biological cell marking technique. Dev Biol 41:162-184.

Liu J, Lauder JM (1992) Serotonin promotes region-specific glial influences on cultured serotonin and dopamine neurons. Glia 5:306-317.

Lo L, Anderson DJ (1995) Postmigratory neural crest cells expressing c-RET display restricted developmental and proliferative capacities. Neuron 15:527-539.

Loric S, Launay J-M, Colas J-F, Maroteaux L (1992) New mouse 5-HT ${ }^{-}$ like receptor. Expression in brain, heart, and intestine. FEBS Lett 312:203-207.

Marshall CJ (1995) Specificity of receptor tyrosine kinase signaling: transient versus sustained extracellular signal-regulated kinase activation. Cell 80:179-185.

Moore MW, Klein RD, Fariñas I, Sauer H, Armanini M, Phillips H, Reichardt LF, Ryan AM, Carver-Moore K, Rosenthal A (1996) Renal and neuronal abnormalities in mice lacking GDNF. Nature 382:76-79.

Nishi M, Whitaker-Azmitia PM, Azmitia EC (1996) Enhanced synaptophysin immunoreactivity in rat hippocampal culture by 5-HT1A agonist, S100b, and corticosteroid receptor agonists. Synapse 23:1-9.

Pham TD, Gershon MD, Rothman TP (1991) Time of origin of neurons in the murine enteric nervous system. J Comp Neurol 314:789-798.

Pichel JG, Shen L, Sheng HZ, Granholm A-C, Drago J, Grinberg A, Lee EJ, Huang SB, Saarma M, Hoffer BJ, Sariola H, Westphal H (1996) Defects in enteric innervation and kidney development in mice lacking GDNF. Nature 382:73-76.

Pomeranz HD, Rothman TP, Chalazonitis A, Tennyson VM, Gershon MD (1993) Neural crest-derived cells isolated from the gut by immunoselection develop neuronal and glial phenotypes when cultured on laminin. Dev Biol 156:341-361.

Roth KA, Hermiston ML, Gordon JI (1991) Use of transgenic mice to infer the biological properties of small intestinal stem cells and to examine the lineage relationships of their descendants. Proc Natl Acad Sci USA 88:9407-9411.

Rothman TP, Gershon MD (1982) Phenotypic expression in the developing murine enteric nervous system. J Neurosci 2:381-393.

Rothman TP, Le Douarin NM, Fontaine-Pérus JC, Gershon MD (1990) Developmental potential of neural crest-derived cells migrating from segments of developing quail bowel back-grafted into younger chick host embryos. Development 109:411-423.

Rothman TP, Le Douarin NM, Fontaine-Pérus JC, Gershon MD (1993) Colonization of the bowel by neural crest-derived cells re-migrating from foregut backtransplanted to vagal or sacral regions of host embryos. Dev Dyn 196:217-233.

Rothman TP, Chen J, Howard MJ, Costantini FD, Pachnis V, Gershon MD (1996) Increased expression of laminin-1 and collagen (IV) subunits in the aganglionic bowel of $l s / l s$, but not $c$-ret $-/-$ mice. Dev Biol 178:498-513.

Sánchez M, Silos-Santiago I, Frisén J, He B, Lira S, Barbacid M (1996) Renal agenesis and the absence of enteric neurons in mice lacking GDNF. Nature 382:70-73.

Sanger F, Nicklen S, Coulson AR (1977) DNA sequencing with chainterminating inhibitors. Proc Natl Acad Sci USA 74:5463.

Sextier-Sainte-Claire Deville F, Ziller C, Le Douarin NM (1994) Developmental potentials of enteric neural crest-derived cells in clonal and mass cultures. Dev Biol 163:141-151.

Shuey DL, Sadler TW, Lauder JM (1992) Serotonin as a regulator of craniofacial morphogenesis: site specific malformation following exposure to serotonin uptake inhibitors. Teratology 46:367-378.

Shuey DL, Sadler TW, Tamir H, Lauder JM (1993) Serotonin and morphogenesis. Transient expression of serotonin uptake and binding protein during craniofacial morphogenesis in the mouse. Anat Embryol (Berl) 187:75-85.

Sieber-Blum M, Ito K, Richardson MK, Langtimm CJ, Duff RS (1993) Distribution of pluripotent neural crest cells in the embryo and the role of brain-derived neurotrophic factor in the commitment to the primary sensory neuron lineage. J Neurobiol 24:173-184.

Siriwardena AK, Smith EH, Borum EH, Kellum Jr J (1993) Identification of a 5-hydroxytryptamine $\left(5-\mathrm{HT}_{2}\right)$ receptor on guinea pig small intestinal crypt cells. Am J Physiol 265:G339-G346. 
Stemple D, Anderson DJ (1992) Isolation of a stem cell for neurons and glia from the mammalian neural crest. Cell 71:973-985.

Tutton PJM (1974) The influence of serotonin on crypt cell proliferation in the jejunum of rat. Virchows Arch B Cell Pathol 16:79-87.

Tutton PJM, Barkla DH (1980) Neural control of colonic cell proliferation. Cancer 45:1172-1177.

Wade PR, Chen J, Jaffe B, Kassem IS, Blakely RD, Gershon MD (1996) Localization and function of a 5-HT transporter in crypt epithelia of the gastrointestinal tract. J Neurosci 16:2352-2364.

Wang H-Y, Eberle-Wang K, Simansky KJ, Friedman E (1993) Serotonin-induced muscle contraction in rat stomach fundus is mediated by a Gaz-like guanine nucleotide binding protein. J Pharmacol Exp Ther 267:1002-1011.

Whitaker-Azmitia PM, Murphy R, Azmitia EC (1990) Stimulation of astroglial $5-\mathrm{HT}_{1 \mathrm{~A}}$ receptors releases the serotonergic growth factor protein, S100, and alters the astroglial morphology. Brain Res 528:155-158.

Wilkinson LD, Lee K, Deshpande S, Duerksen-Hughes P, Boss JM, Pohl
J (1989) The neuron-specific protein PGP 9.5 is a ubiquitin carboxylterminal hydrolase. Science 246:670-673.

Yan L, Zahradka P (1997) Immunodetection of activated mitogenactivated protein kinase in vascular tissues. Mol Cell Biochem 172:59-66.

Yang W, Chen K, Lan NC, Gallaher TK, Shih JC (1992) Gene structure and expression of the mouse 5- $\mathrm{HT}_{2}$ receptor. J Neurosci Res 33:196-204.

Yntema CL, Hammond WS (1954) The origin of intrinsic ganglia of trunk viscera from vagal neural crest in the chick embryo. J Comp Neurol 101:515-542.

Yntema CL, Hammond WS (1955) Experiments on the origin and development of the sacral autonomic nerves in the chick embryo. J Exp Zool 129:375-414.

Yu L, Nguyen H, Le H, Bloem LJ, Kozak CA, Hoffman BJ, Snutch TP, Lester HA, Davidson N, Lübbert H (1991) The mouse 5-HT 1 receptor contains eight hydrophobic domains and is X-linked. Mol Brain Res 11:143-149. 